\title{
NEW MARINE $\triangle$ R VALUES FOR THE SOUTH PACIFIC SUBTROPICAL GYRE REGION
}

\author{
Fiona Petchey ${ }^{1,2} \bullet$ Atholl Anderson ${ }^{3} \cdot$ Albert Zondervan $^{4} \bullet$ Sean Ulm ${ }^{5}$ Alan Hogg ${ }^{1}$
}

ABSTRACT. This paper presents 31 new $\Delta \mathrm{R}$ results of known-age, pre-AD 1950 shells from the South Pacific subtropical gyre region, spanning from the Tuamotu Archipelago in the east to New Caledonia in the west. This doubles the number of available $\Delta R$ values for the Oceania region. These values indicate that the regional offset $(\Delta R)$ from the modeled radiocarbon marine age has remained relatively constant over the last $100 \mathrm{yr}$ prior to 1950 . Variation from the norm can be attributed to various influences including localized upwelling around islands, the presence of a hardwater effect, direct ingestion of old carbon by the live shellfish, or enhanced exchange with atmospheric $\mathrm{CO}_{2}$ as a consequence of photosynthetic activity or increased aeration.

\section{INTRODUCTION}

The surface ocean (down to around $200 \mathrm{~m}$ depth) has an apparent radiocarbon age that is, on average, $400 \mathrm{yr}$ older than associated materials from the terrestrial (atmospheric) reservoir. This is known as the marine reservoir effect. It is caused both by a delay in ${ }^{14} \mathrm{C}$ exchange between the atmosphere and ocean, and by the mixing of surface waters with upwelled, ${ }^{14} \mathrm{C}$-depleted deep ocean water (Stuiver et al. 1986). This reservoir effect is automatically corrected for when a marine shell conventional radiocarbon age (CRA) ${ }^{6}$ is calibrated using the modeled marine ${ }^{14} \mathrm{C}$ calibration curve (e.g. Marine04: Hughen et al. 2004), which represents a global average of the surface ocean ${ }^{14} \mathrm{C}$ as it changes over time. The calibration of marine samples is complicated by local and regional deviation from this global average. To account for this deviation, a local correction factor, or $\Delta \mathrm{R}$ - the difference between the modeled ${ }^{14} \mathrm{C}$ age of surface water and the actual ${ }^{14} \mathrm{C}$ age of surface water at that locality - needs to be determined (Stuiver et al. 1986). This can be calculated from marine samples from known locations collected prior to AD 1950, whose age of death is known precisely (i.e. annually banded corals, shells and/or otoliths of surface dwelling fish) (e.g. Kalish 1993; Dye 1994; Guilderson et al. 2000; Petchey et al. 2004) or from contemporaneous terrestrial/marine samples typically from archaeological deposits (e.g. Reimer et al. 2002; Ulm 2002; Jones et al. 2007) or tephra deposits that act as onshore/offshore isochrons (Sikes et al. 2000).

Data collected over the last decade (see the Marine Reservoir Database [Reimer and Reimer 2005]) suggest that $\Delta \mathrm{R}$ values from pre-AD 1950 marine proxies in the Pacific vary significantly across the region. A recent assessment of these values by Petchey (in press) highlights a number of shortcomings with extant $\Delta \mathrm{R}$ values, including questionable collection dates, the dating of unsuitable species, and limited provenance information. This limited number of reliable $\Delta \mathrm{R}$ values is a problem for researchers trying to obtain accurate calibrated results of marine shell and other animals that subsisted on marine resources (e.g. human [Petchey and Green 2005; Nunn et al. 2007a,b]; Pacific rat [Anderson et al. 2001], pig [Beavan Athfield et al. 2008], or turtle bone [Petchey 2001]).

In this paper, we address this problem for the marginal southwest Pacific and central East Polynesia, specifically French Polynesia (i.e. Society Islands, Marquesas Islands, Tuamotu Archipelago, Gam-

\footnotetext{
${ }^{1}$ Radiocarbon Dating Laboratory, University of Waikato, Hamilton, New Zealand.

${ }^{2}$ Corresponding author. Email: fpetchey@ waikato.ac.nz.

${ }^{3}$ Research School of Pacific and Asian Studies, Australian National University.

${ }^{4}$ National Isotope Centre, GNS Science, Lower Hutt, New Zealand.

${ }^{5}$ Aboriginal and Torres Strait Islander Studies Unit, University of Queensland, Australia.

${ }^{6} \mathrm{~A}$ conventional radiocarbon age (CRA) is obtained from a ${ }^{14} \mathrm{C}$ measurement following the conventions set out by Stuiver and Polach (1977).
} 
bier Islands, and the Austral Islands), the Cook Islands, Vanuatu Islands, Fiji, New Caledonia, Santa Cruz Islands, Tongan Archipelago and the Samoan Archipelago. To this end, we present 31 new $\Delta R$ values obtained from known-age, pre-AD 1950 marine shells and compare these to extant published values from this region (see Figure 1 and Table 1).

\section{METHODOLOGY}

${ }^{14} \mathrm{C}$ dating of marine organisms whose calendar date of death is well documented enables comparison of the atmospheric and marine ${ }^{14} \mathrm{C}$ contents at a specific time and location. This comparison necessitates that samples selected for analysis conform to a number of prerequisites as laid out in Petchey (in press):

1. The marine sample must have been collected live, or the date of death independently validated. For "historic," known-age shells, this can best be demonstrated by museum documentation, the presence of fleshy remains of an animal, or valves in articulation with intact ligaments.

2. The geographic location where the samples were collected must be known.

3. The marine sample must be identified to genus level (preferably species), and the dietary and habitat preferences of that species must closely represent that of the reservoir being investigated (e.g. open ocean, estuarine, etc.).

4. For museum specimens, the date of collection must be known and be before AD 1950 (i.e. prior to detonation of thermonuclear devices, which added ${ }^{14} \mathrm{C}$ into the atmosphere). This "bomb effect" shows up in coral core records from the North Pacific as early as 1956 (Konishi et al. 1982) and 1957 in the South Pacific (Toggweiler et al. 1991; Druffel and Griffin 1993).

Suspension feeders (also known as filter feeders) were preferentially selected for this research as these typically consume suspended phytoplankton and dissolved inorganic carbon from seawater, and are usually considered the most reliable shells for ${ }^{14} \mathrm{C}$ dating because they more closely reflect the ${ }^{14} \mathrm{C}$ content of the ocean mixed surface layer (Forman and Polyak 1997; Hogg et al. 1998). Even with these suspension-feeding shellfish, the effect of different sources of ${ }^{14} \mathrm{C}$ depends upon the degree of water exchange with the open ocean, ocean circulation, and the habitat and diet of the marine animal investigated (Tanaka et al. 1986; Hogg et al. 1998; Petchey et al. 2004). In a couple of instances, carnivorous shellfish have also been dated. Little information is available for carnivorous shellfish, but they are presumed to show an averaging effect depending on the carbon reservoirs of their prey and could, therefore, be subject to similar uncertainties as their prey. In these situations, the analysis of oxygen and carbon stable isotopes in combination with $\Delta \mathrm{R}$ data can be used to distinguish between different environmental influences on marine shell (Culleton et al. 2006; Petchey et al. 2008). In particular, $\delta^{18} \mathrm{O}$ is a highly sensitive indicator of change in water temperature and salinity, while the $\delta^{13} \mathrm{C}$ value of marine shells is thought to predominantly reflect changes in water source and overall marine productivity (Keith et al. 1964; Killingley and Berger 1979; Kennett et al. 1997). The effect of ingestion of limestone by herbivores and deposit-feeding species is well documented (Dye 1994; Anderson et al. 2001), and these species were not sampled.

New samples for $\Delta \mathrm{R}$ analysis were obtained from mollusk collections housed at the Australian Museum, National Museum of New Zealand, Auckland War Memorial Museum (New Zealand), and the Museum of Natural History (Paris). In some cases, museum documentation was incomplete or ambiguous. It was necessary, therefore, to obtain independent support from published sources for the collection date and geographic sampling location, in addition to evidence that the shells were collected live. This information is given in Appendix 1. This kind of information is often lacking for extant published $\Delta \mathrm{R}$ values; therefore, less confidence can be placed in these values (Petchey, in press). 

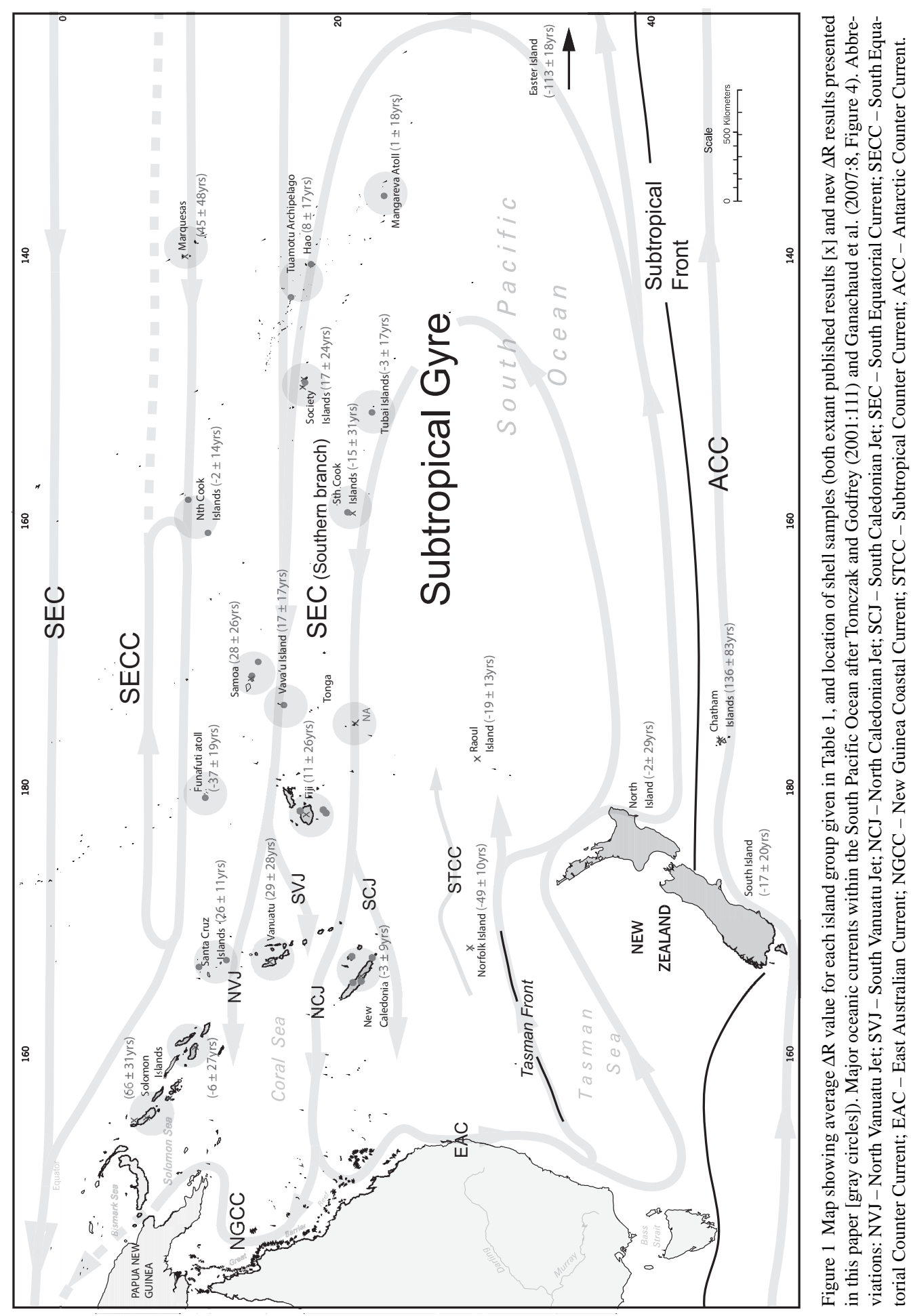


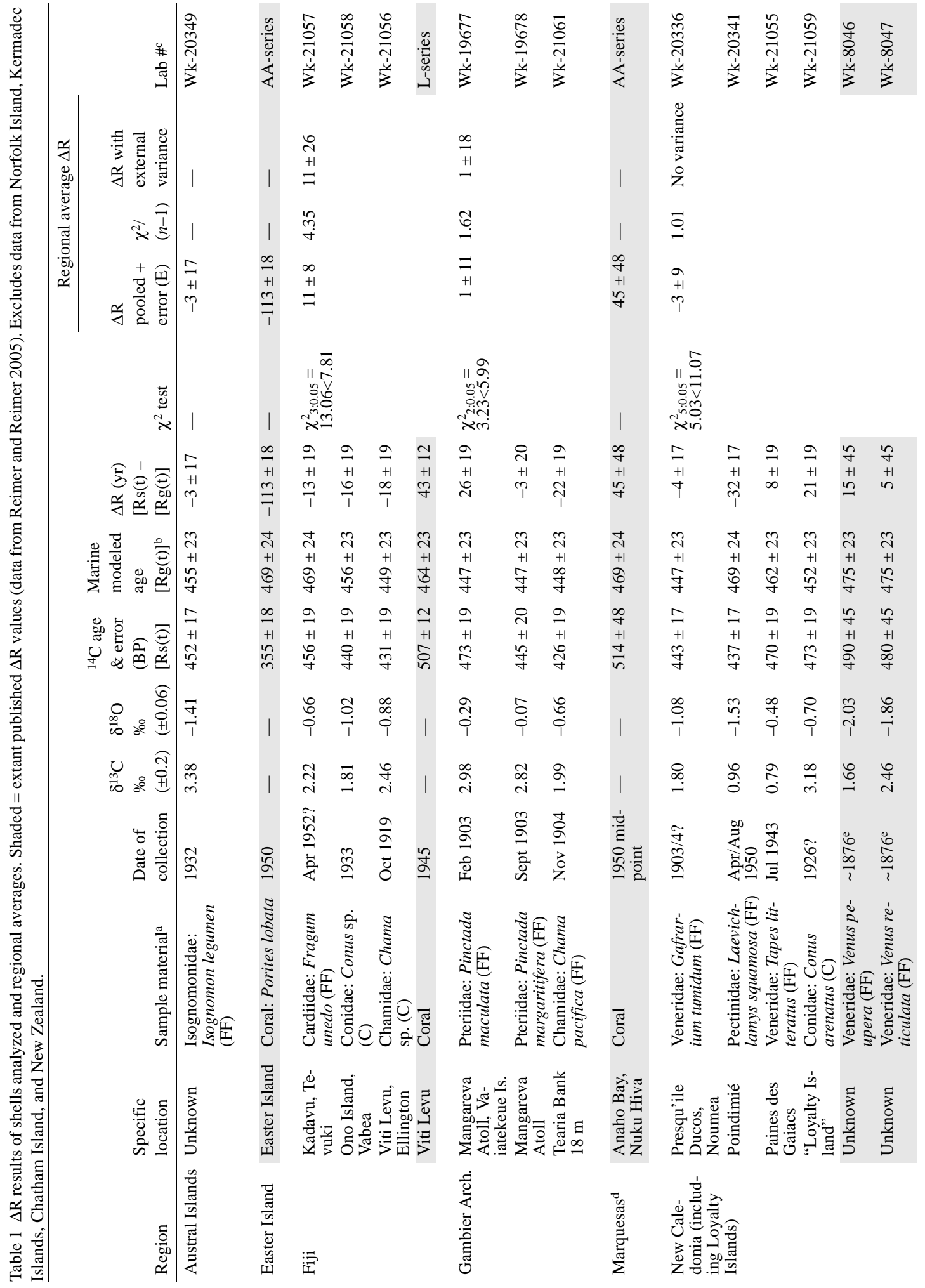




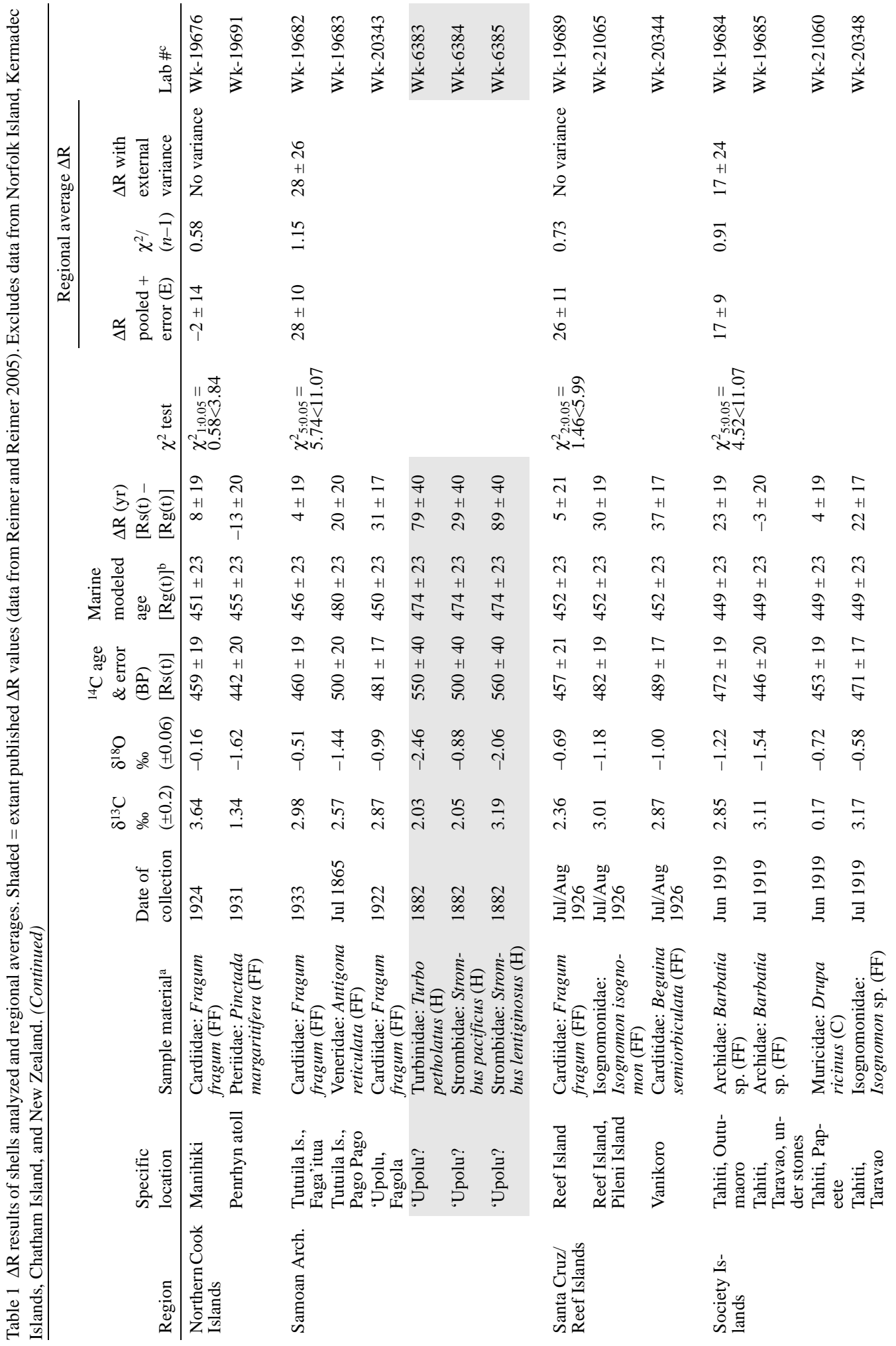




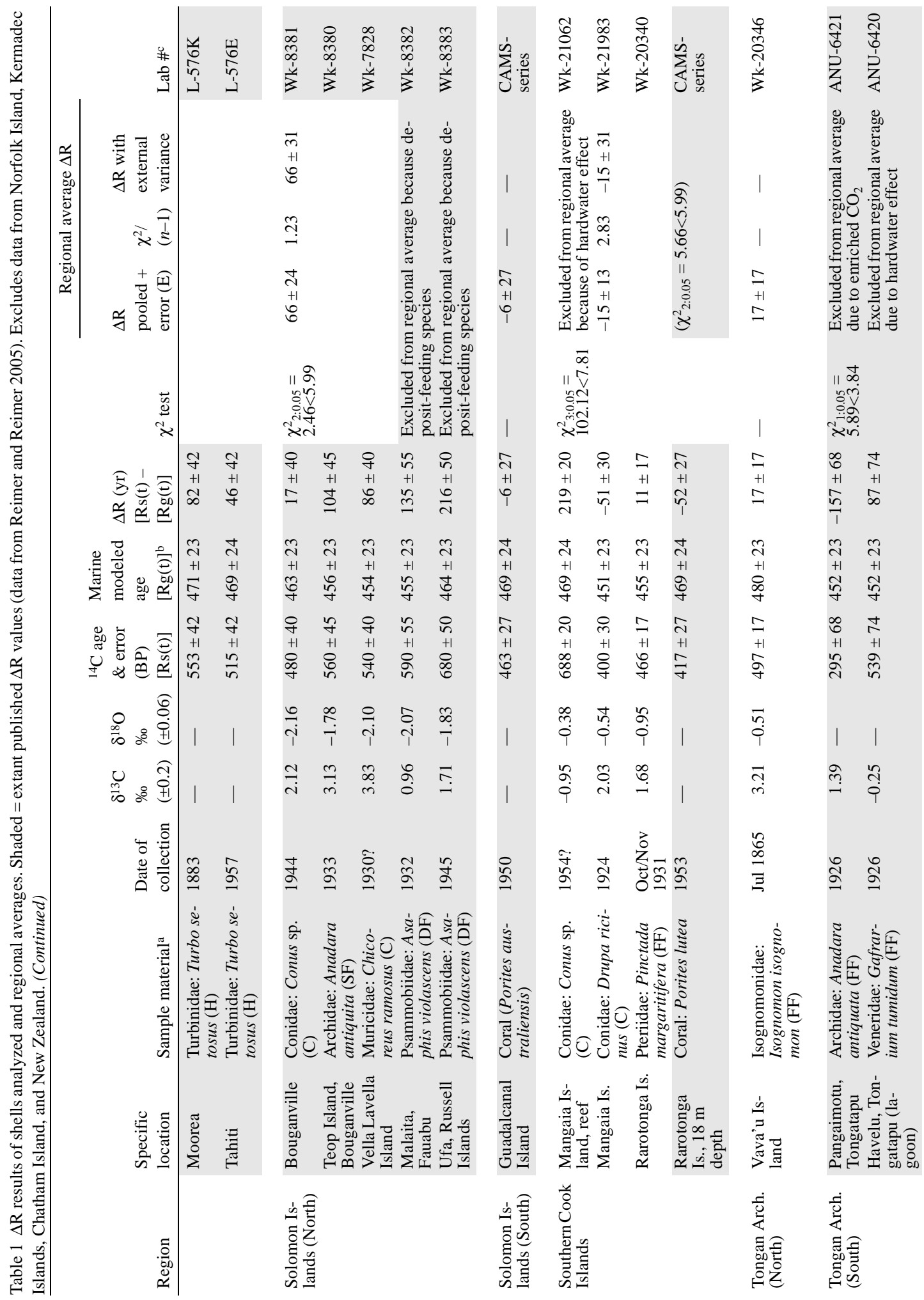




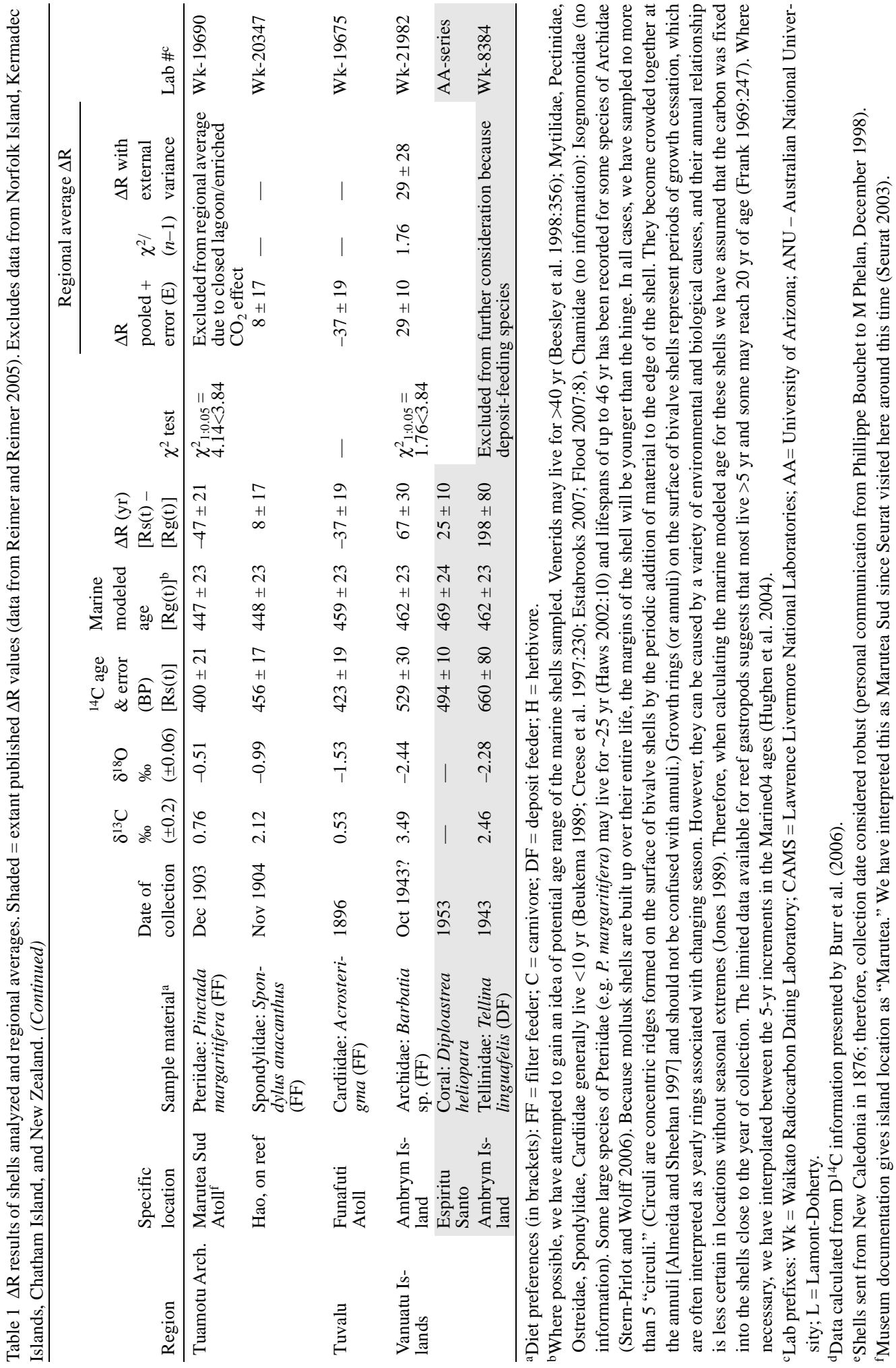


From each of these shells, we removed a 5-mm cross-section perpendicular to the edge across multiple increments of growth to avoid intrashell variations in ${ }^{14} \mathrm{C}$ (cf. Culleton et al. 2006) and provide an average value over a maximum period of $5 \mathrm{yr}$ (i.e. 1 increment in the Marine04 data set). This should avoid errors introduced by the variable lifespan of different shellfish species, but also avoid seasonal fluctuation in stable isotope values (Keith et al. 1964). Samples were washed in dilute $\mathrm{HCl}$ to remove surface contamination. They were then reacted with orthophosphoric acid and $\mathrm{CO}_{2}$ converted to graphite at the Waikato Radiocarbon AMS facility, and compressed into a target for analysis at the National Isotope Centre, GNS Science, Wellington. $\delta^{18} \mathrm{O}$ and $\delta^{13} \mathrm{C}$ values were measured on gas splits taken during preparation of samples for accelerator mass spectrometry (AMS) analysis at the University of Waikato using a Europa Scientific Penta 20-20 isotope ratio mass spectrometer. For each of the ${ }^{14} \mathrm{C}$ results, the $\Delta \mathrm{R}$ for a specific location "(s)" was calculated from using the formula $\mathrm{Rs}(\mathrm{t})-\operatorname{Rg}(\mathrm{t})=\mathrm{R}(\mathrm{s})$, where $(\mathrm{R}(\mathrm{s}))$ is the difference between the global average $(\operatorname{Rg}(\mathrm{t}))$ and the actual ${ }^{14} \mathrm{C}$ activity of the surface ocean at a particular location $(\mathrm{Rs}(\mathrm{t}))$ at that time. Each individual $\Delta \mathrm{R}$ standard error is calculated by the formula $\Delta \mathrm{R} \sigma=\sqrt{ }\left(\sigma_{\mathrm{Rg}(\mathrm{t})}{ }^{2}+\sigma_{\mathrm{Rs}(\mathrm{t})}{ }^{2}\right)$ (Stuiver et al. 1986). We have chosen not to apply any correction for fossil fuel input (Suess 1955) to the $\Delta \mathrm{R}$ values presented in this paper on the basis that the regional and global surface ocean act in parallel to atmospheric forcing (Reimer et al. 2002).

Even when samples are carefully selected according to the prerequisites listed above, there are a number of uncertainties in $\Delta \mathrm{R}$ values associated with the postulated time of carbon uptake before collection and the influence of diet, habitat, and short-term fluctuation in the water masses. When calculating the amount of uncertainty introduced by the non-uniform ${ }^{14} \mathrm{C}$ content of the shellfish when combining several $\Delta \mathrm{R}$ values for a region, the standard approach has been to calculate the scatter $\sigma$ in the unweighted mean (i.e. the empirical standard deviation $=\sigma / \sqrt{ } n$ ) and compare this to the weighted mean, taking the larger of the 2 as the $\Delta \mathrm{R}$ uncertainty ( \pm ) following the recommendations of Stuiver et al. (1986:982). Reimer and Reimer (2006) recently advocated the use of the standard deviation $(\sigma)$ as a more accurate assessment of $\Delta \mathrm{R}$ variability. Alternatively, we have calculated the weighted mean for each island group (Table 1) using the $\chi^{2}$ test to evaluate the internal variability in a group of $\Delta \mathrm{R}$ values (cf. Ward and Wilson 1978). If the group has additional measurement variability (as indicated if $\chi^{2} /(n-1)$ is $>1$ ), an additional uncertainty is calculated and applied to the $\Delta \mathrm{R}$. This additional uncertainty is calculated by $\sqrt{ }\left(s_{\Delta \text { Rpooled }}^{2}+\sigma_{\text {ext }}^{2}\right)$, whereby the external standard deviation $\left(\sigma_{\text {ext }}\right)$ is determined by subtracting the ${ }^{14} \mathrm{C}$ measurement variance from the total population variance and obtaining the square root (e.g. $\sigma_{\text {ext }}=\sqrt{ }\left(\sigma_{\text {pop }}^{2}-\sigma_{\text {meas }}^{2}\right)$ ) (see Bondevik and Gulliksen in Mangerud et al. 2006:3241-2 for explanation). When $\chi^{2 /(n-1)}$ is $\leq 1$, the weighted mean is used.

\section{RESULTS AND DISCUSSION}

We have obtained $\Delta \mathrm{R}$ values for 31 pre-AD 1950, known-age shell samples from the South Pacific (Table 1). An additional $22 \Delta \mathrm{R}$ values have previously been reported (see Petchey [in press] for references). Unfortunately, many of these published $\Delta \mathrm{R}$ values are of herbivores or deposit-feeding shellfish. We have excluded $\Delta R$ values measured on deposit feeders from further analysis, but $\Delta R$ values on herbivores from locations dominated by volcanic geologies have been included for consideration (Tables 1 and 2). Figure 1 shows the geographic origin of these samples grouped into 18 regions covering about $300 \mathrm{~km}$ radius. We have not been able to locate any additional pre-AD 1950 historic shells from Easter Island, Pitcairn, or the Marquesas and only 1 value was obtained from the Tongan Archipelago and Vanuatu Islands. Large gaps also remain throughout the South Pacific in areas with small isolated atolls. Despite gaps in the data, the evaluation of extant $\Delta \mathrm{R}$ values (Petchey, in press) in combination with these 31 new $\Delta \mathrm{R}$ values provides greater insight into marine reservoir variation in the South Pacific. 
Table 2 Sample locations showing underlying geology.

\begin{tabular}{|c|c|c|c|}
\hline Island group & Specific location & Island type*a & Reference \\
\hline Austral Islands & "Tubai islands" & $\begin{array}{l}\text { Volcanic islands (minor limestone present } \\
\text { on Rapa, Rurutu, and Rimatara are encir- } \\
\text { cled by makatea }^{\text {b }} \text { ) }\end{array}$ & Chubb 1927 \\
\hline Easter Island & Easter Island & Volcanic island & Baker et al. 1974 \\
\hline \multirow[t]{3}{*}{ Fiji } & Kandavu & Volcanic island & \multirow[t]{2}{*}{ Nunn and Omura 1999} \\
\hline & Ono Is. Vambea & Volcanic island & \\
\hline & Viti Levu, Ellington & $\begin{array}{l}\text { Ancient volcanic island (no limestone re- } \\
\text { corded at Ellington) }\end{array}$ & Rodda and Band 1966 \\
\hline Gambier Arch. & Mangareva & $\begin{array}{l}\text { Volcanic almost atoll* } \\
\text { Open: Elevated island atoll tilted slightly } \\
\text { resulting in submergence of atoll ring to } S \\
\text { and } E\end{array}$ & Kirch 2004 \\
\hline Marquesas & Nuku Hiva & Volcanic island & $\begin{array}{l}\text { Savanier et al. 2003; } \\
\text { Chubb } 1930\end{array}$ \\
\hline \multirow[t]{4}{*}{ New Caledonia } & $\begin{array}{l}\text { Presqu'ile Ducos, } \\
\text { Noumea }\end{array}$ & $\begin{array}{l}\text { Continental bedrock island (minor lime- } \\
\text { stone present at all locations) }\end{array}$ & $\begin{array}{l}\text { Lillie and Brothers } \\
1970 ; \text { Paris } 1981\end{array}$ \\
\hline & Poindimié & & \\
\hline & Paines des Gaiacs & & \\
\hline & Loyalty Is. & Carbonate islands & Guillon 1974 \\
\hline \multirow{3}{*}{$\begin{array}{l}\text { Northern Cook } \\
\text { Islands }\end{array}$} & Manahiki & Coral atoll* & \multirow[t]{2}{*}{ Wood and Hay 1970} \\
\hline & & $\begin{array}{l}\text { Open restricted: Shallow passages occur } \\
\text { to the N. Lagoon depth varies. }\end{array}$ & \\
\hline & Penrhyn & $\begin{array}{l}\text { Coral atoll * } \\
\text { Open: Deep passages on the NE and NW }\end{array}$ & Wood 1967 \\
\hline \multirow[t]{2}{*}{ Samoan Arch. } & Tutuila Island & Volcanic island & \multirow[t]{2}{*}{ Keating 1992} \\
\hline & 'Upolu Island & Volcanic island & \\
\hline \multirow{3}{*}{$\begin{array}{l}\text { Santa Cruz/Reef } \\
\text { Islands }\end{array}$} & Reef Island & Limestone island & \multirow{3}{*}{$\begin{array}{l}\text { British Solomon Is- } \\
\text { lands, Dept. of Geolog- } \\
\text { ical Surveys } 1969 \\
\text { Dennis } 1981\end{array}$} \\
\hline & $\begin{array}{l}\text { Reef Is., Pilini Is., on } \\
\text { coral reef }\end{array}$ & Unconsolidated island & \\
\hline & $\begin{array}{l}\text { Santa Cruz Is., Vani- } \\
\text { koro }\end{array}$ & Volcanic island & \\
\hline \multirow[t]{3}{*}{ Society Islands } & Tahiti, Outu Maoro & Volcanic island & \multirow[t]{2}{*}{ Williams 1933} \\
\hline & Moorea & Volcanic island & \\
\hline & Maupiti & Volcanic almost atoll & $\begin{array}{l}\text { Rougerie and Wauty } \\
1993\end{array}$ \\
\hline \multirow[t]{6}{*}{ Solomon Islands } & Bouganville & Contintental island & $\begin{array}{l}\text { Blake and Miezitis } \\
1967\end{array}$ \\
\hline & Bouganville Teop Is. & Continental island & \multirow[t]{5}{*}{ Hughes et al. 1981} \\
\hline & Vella Lavella Island & Volcanic island & \\
\hline & Malaita, Fauabu & Continental island & \\
\hline & Ufa Island, Russell Is. & Volcanic island with makatea ${ }^{b}$ & \\
\hline & Guadalcanal Island & Continental island & \\
\hline \multirow{3}{*}{$\begin{array}{l}\text { Southern Cook } \\
\text { Islands }\end{array}$} & Aitutaki & Volcanic "almost atoll" & \multirow{3}{*}{$\begin{array}{l}\text { Waterhouse and Petty } \\
\text { 1986; Wood } 1967\end{array}$} \\
\hline & Rarotonga & Volcanic island (minor limestone) & \\
\hline & Mangaia & Volcanic island with makatea ${ }^{\mathrm{b}}$ & \\
\hline
\end{tabular}


Table 2 Sample locations showing underlying geology. (Continued)

\begin{tabular}{|c|c|c|c|}
\hline Island group & Specific location & Island type*a & Reference \\
\hline \multirow[t]{2}{*}{ Tongan Arch. } & Tongatapu & Carbonate island & \multirow[t]{2}{*}{ Roy 1990} \\
\hline & Vava'u Island & Carbonate island & \\
\hline \multirow[t]{4}{*}{ Tuamotu Arch. } & Marutea Sud & Coral atoll* & \multirow[t]{2}{*}{ Chevalier 1972} \\
\hline & & $\begin{array}{l}\text { Closed: Water exchange occurs only dur- } \\
\text { ing storms }\end{array}$ & \\
\hline & Hao & Coral atoll* & \multirow[t]{2}{*}{ Salvat (1985) } \\
\hline & & Open: 1 narrow pass to $\mathrm{N}$ & \\
\hline \multirow[t]{2}{*}{ Tuvalu } & Funafuti & Coral atoll $*$ & \multirow[t]{2}{*}{ Oceandots.com 2008} \\
\hline & & $\begin{array}{l}\text { Open: Deep lagoon. Shallow passage is } \\
\text { available on the } E \text { and } W \text { edge of lagoon }\end{array}$ & \\
\hline \multirow[t]{3}{*}{ Vanuatu Islands } & Ambrym & Volcanic island & British Government, \\
\hline & & & Development 1976 \\
\hline & Espiritu Santo & Ancient volcanic island (major limestone) & $\begin{array}{l}\text { Mallick and Green- } \\
\text { baum 1977; Macfar- } \\
\text { lane et al. } 1983\end{array}$ \\
\hline
\end{tabular}

a $*$ = The classification of Open/Closed atoll is based on Salvat (1985) where open and closed mean, respectively, with and without a pass. Additional information is required to assess residence time of water within the lagoon.

${ }^{\mathrm{b}}$ Makatea $=$ fossil coral reef.

The region under study is encircled by the South Pacific Subtropical Gyre, a circulatory system driven by the combined effects of the tropical tradewinds and the westerly winds in the subtropical regions. This results in the high-latitude eastward-flowing Antarctic Circumpolar Current (ACC) and the mid-latitude westward-flowing South Equatorial Current (SEC). The SEC transports water from the center of the gyre and bifurcates on the east coast of Australia, feeding both the East Australian Current (EAC) and the New Guinea Coastal Current (NGCC) (Figure 1). This circulatory system is considered to create relatively stable surface water conditions at the center of the gyre (Rougerie and Wauty 1993). The $\Delta \mathrm{R}$ values presented in Table 1 and Figure 2 are generally low and uniform across the region, in keeping with these observations.

Variation does exist in our data set, however, as indicated by the $\chi^{2}$ statistics for the Tuamotu Archipelago $\left(\chi_{1: 0.05}^{2}=4.14<3.84\right)$, Southern Cook Islands $\left(\chi^{2} 3: 0.05=102.12<7.81\right)$, Fiji $\left(\chi^{2} 3: 0.05=\right.$ $13.06<7.81)$, and Tongatapu $\left(\chi_{1: 0.05}^{2}=5.89<3.84\right)$ (Table 1$)$. This spread in values signifies nonuniform ${ }^{14} \mathrm{C}$ content in the shellfish, and hints at a more complex picture than previously recognized by researchers utilizing marine samples from the South Pacific for dating purposes. We hypothesize several causes for this variation below.

\section{Ocean Boundaries}

At the boundaries of the Pacific Ocean, a complex interplay occurs between ocean currents and the continental landmasses (Figure 1). For example, Petchey et al. (2004) noted large variations in $\Delta R$ over short distances in the Bismarck Sea, where seasonal reversals in the SEC and North Equatorial Counter Current resulted in localized upwelling. $\Delta \mathrm{R}$ variation has also been noted in shells from areas of upwelling along the eastern edge of the Pacific Ocean: along the Californian coastline (Culleton et al. 2006) and the Peru/Chile coastline (Taylor and Berger 1967). Less obvious boundaries can be caused by the interaction of different oceanic current systems. In the South Pacific, there are 3 major changes in water body: the Subtropical Front, Tasman Front, and the Equator. Large fluctu- 
ations in $\Delta \mathrm{R}$ occur at the Galapagos Islands due to Ekman upwelling from the Equator (Taylor and Berger 1967; Druffel et al. 2004) which occurs when the wind-driven component of transport in the surface ocean moves perpendicular to the mean wind stress, causing divergence in the surface water and upwelling of water depleted in ${ }^{14} \mathrm{C}$ (Tomczak and Godfrey 2001:41). Further south, the boundary between Subtropical and Antarctic water (Subtropical Front) forces ${ }^{14} \mathrm{C}$-depleted water upwards just off the east coast of the South Island of New Zealand and along the southern flank of the Chatham Rise, resulting in high and variable $\Delta \mathrm{R}$ values (Petchey et al. 2008). Lower $\Delta \mathrm{R}$ values have been recorded for islands located in the Tasman Front (Norfolk and Kermadec Islands), which are attributed to high air-sea ${ }^{14} \mathrm{C}$ exchange and heightened absorption of atmospheric $\mathrm{CO}_{2}$ associated with enhanced biological production in the rich waters of the front (Petchey et al. 2008).

Disturbance to the dominant water flow by island chains impinging on the oceanic currents may also result in significant $\Delta \mathrm{R}$ variation. Petchey (in press) has speculated that oceanic conditions around the Hawaiian Islands may, in part, be responsible for some of the variation observed by Dye (1994) (ranging from $-29 \pm 4$ to $280 \pm 80{ }^{14} \mathrm{C}$ yr). Interaction between the Hawaiian Island chain and northeasterly tradewinds result in upwelling and downwelling in the lee of the islands, as well as the formation of large-scale eddies formed in the $25 \mathrm{~cm} \mathrm{~s}^{-1}$ flow of the North Equatorial Current. Petchey et al. (2004) have also hypothesized that variable $\Delta \mathrm{R}$ values for the Solomon chain of islands were caused, in part, by the disturbance of the SEC creating localized eddies and wakes (Figure 2). This observation is supported by research into surface chlorophyll variability in this region (Messié and Radenac 2006). Large-scale eddies have also been documented along the southeast coastline of Australia at the boundary between warm water of the Coral Sea and the cooler water of the Tasman Sea (Tomczak and Godfrey 2001:126-8), and around the east coast of New Zealand (Ridgway and Dunn 2003). The surface currents around the Marquesas are also strong enough to create zonal currents and fluctuating eddies (Martinez and Maamaatuaiahutapu 2004) and seasonal variation has been recorded (Signorini et al. 1999:3122), but additional values from the Marquesas are needed to evaluate the true extent of any variability.

Given that $\Delta \mathrm{R}$ variation can be caused by disruption to the ocean currents, variable $\Delta \mathrm{R}$ should be expected for the Fiji, New Caledonian, and Vanuatu island chains. These islands impinge on the SEC, dividing the southern branch into 3 main jets: South Caledonian Jet (SCJ), North Caledonian Jet (NCJ), and North Vanuatu Jet (NVJ) (Ganachaud et al. 2007) (see Figure 1). The NVJ is fairly broad (with a slow flow of $10 \mathrm{~cm} \mathrm{~s}^{-1}$ ). ${ }^{7}$ The NCJ, on the other hand, is narrow and speeds of more than $20 \mathrm{~cm} \mathrm{~s}^{-1}$ are reached at the northern tip of New Caledonia (Gourdeau et al. 2008), causing eastward flows that may generate an eddy field in the lee of the island. These conditions also result in the development of dominant currents on the eastern side of New Caledonia and upwelling on the southwest coast (Ganachaud et al. 2007:20) analogous to that recorded for the Hawaiian chain of islands. The combined effect of zonal jets and island interaction with the Southeast Tradewinds also creates weak eastward flowing currents in the lee of Vanuatu (i.e. Coral Sea Countercurrent) and Fiji (i.e. Fiji Basin Countercurrent) along $16^{\circ} \mathrm{S}$ and $18^{\circ} \mathrm{S}$, respectively, with enhanced eddy variability in these regions (Qiu et al., in press). Available oceanographic data is currently too limited to outline the full extent of surface ocean conditions in these regions.

A total of $4 \Delta \mathrm{R}$ values are now available for Fiji, providing an average value of $11 \pm 26{ }^{14} \mathrm{C}$ yr $\left(\chi^{2} 3: 0.05=13.06<7.81\right)($ Table 1$)$. Two of the values come from Viti Levu; the other $2 \Delta \mathrm{R}$ values are from the offshore islands of Kandavu (Tevuki) and Ono Island, Vabea. Within this data set, the

${ }^{7}$ Swift flows in excess of $20 \mathrm{~cm} \mathrm{~s}^{-1}$ are necessary to form eddies or wakes around the islands (Andrews and Pickard 1990; Heywood et al. 1990). 


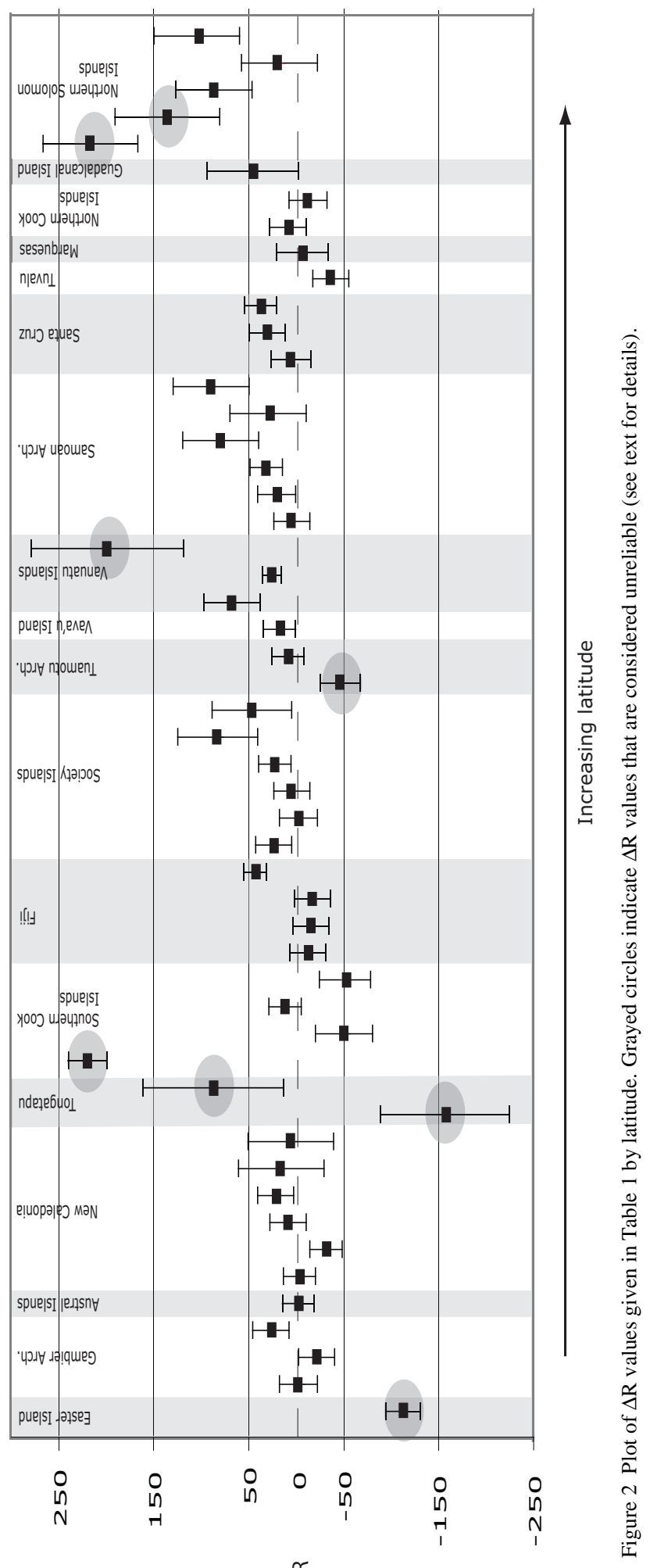

$\dddot{q}$ 
$\Delta \mathrm{R}$ outlier is a value of $43 \pm 12{ }^{14} \mathrm{C}$ yr from coral core data published by Toggweiler et al. (1991). Without further information on the precise collection location for this particular sample, it is impossible to know if this value is a function of localized upwelling associated with variability in the currents around the islands. Conversely, a combined $\Delta \mathrm{R}$ for the 6 values from New Caledonia and "Loyalty Island" result in a value of $-3 \pm 9{ }^{14} \mathrm{C}$ yr with no external variance $\left(\chi^{2}\right.$ 5:0.05 $=$ $5.03<11.07$ ) (Table 1). This is unexpected given the observations outlined above. It is possible that the extensive barrier reef extending either site of New Caledonia protects the enclosed lagoon, creating a more uniform environment. We think it is likely, therefore, that additional marine shells from New Caledonia may give anomalous ${ }^{14} \mathrm{C}$ results especially at the northern extent of the island or where the barrier reef is patchy. Limited data is available from the Vanuatu Islands and precludes evaluation of the regional Vanuatu $\Delta \mathrm{R}$ at this time.

\section{Habitat Effect}

In the central zone of the gyre, the flows are weak (about 5-10 $\mathrm{cm} \mathrm{s}^{-1}$ ) (Rougerie and Rancher 1994). Theoretically, any variation to $\Delta \mathrm{R}$ should therefore be predominantly caused by habitat-specific influences, many of which will have a small geographic range. Such influences include the incorporation of carbon derived from peat, dissolved (i.e. hardwaters) or particulate carbonates derived from calcareous bedrock (Keith et al. 1964; Dye 1994; Spennemann and Head 1998) and volcanic activity, all of which result in high $\Delta \mathrm{R}$ values. Lower $\Delta \mathrm{R}$ values have been attributed to the incorporation of freshwater derived from riverborne dissolved and particulate organic matter or rainfall (Stuiver and Braziunas 1993; Dye 1994; Southon et al. 2002), high air-sea ${ }^{14} \mathrm{C}$ exchange coupled with reduced mixing with older subsurface waters (Guilderson et al. 2000), heightened absorption of atmospheric $\mathrm{CO}_{2}$ associated with enhanced biological production (Petchey et al. 2008), and increased wind and wave action (Forman and Polyak 1997:888; Hogg et al. 1998).

\section{Hardwater}

Hardwaters contain large amounts of bicarbonate ions, which are generated by seepage through calcareous strata. Organisms that live within these hardwaters indirectly take up ${ }^{14} \mathrm{C}$ derived from those strata. Consequently, shellfish that inhabit environs within a limestone catchment may yield a ${ }^{14} \mathrm{C}$ age that is excessively old (Dye 1994; Petchey et al. 2008). Spennemann and Head (1998) suggested a $\Delta \mathrm{R}$ of $87 \pm 74{ }^{14} \mathrm{C} \mathrm{yr}$ from Havelu Lagoon, Tongatapu, was caused by waters draining through Pliocene and Pleistocene limestone. Although the precision of this particular value limits further evaluation of this hypothesis, an anomalous value for Mangaia Island in the Southern Cook Islands $\left(\Delta \mathrm{R}=219 \pm 20{ }^{14} \mathrm{C} \mathrm{yr}\right)$ is almost certainly caused by uptake of ${ }^{14} \mathrm{C}$ from the limestone bedrock (Table 2). Mangaia is composed of a central volcanic core surrounded by an almost continuous ring of Pleistocene limestone cliffs (makatea) (Waterhouse and Petty 1986). All streams on the island drain through underground channels in the raised limestone and many discharge as springs at the coast (Wood 1967). The $\delta^{13} \mathrm{C}$ value for Wk-21062 from Mangaia (-0.95\%) is more depleted than the typical range $(0.9 \%$ and $2.1 \%$ ) for modern South Pacific surface-ocean dissolved inorganic carbon (DIC) (Gruber et al. 1999; Tagliabue and Bopp 2008: Figure 2) (see also Havelu [ANU-6420], which has a $\delta^{13} \mathrm{C}$ of $-0.25 \%$ o) ${ }^{8}$ However, any input of freshwater should result in the depletion of both $\delta^{13} \mathrm{C}$ and $\delta^{18} \mathrm{O}$, which does not seem to be the case for Wk-21062 (Keith et al. 1964:1781; Gat 1996:241,

\footnotetext{
${ }^{8}$ Most shellfish precipitate their shells in equilibrium with the stable isotopes in the local environment, but some may display an offset because of metabolic or kinetic effects (i.e. growth rate) (Keith et al. 1964; Goewert et al. 2007). A difference in $\delta^{18} \mathrm{O}$ between calcite and aragonite has also been noted in some shellfish (Rick et al. 2006), but this has been attributed to differential equilibrium conditions between the interior and exterior of the shell rather than shell chemistry (Keith et al. 1964; Kirby et al. 1998). Because of the nature of sampling in this study, this interior bias should not be present.
} 
255; Culleton et al. 2006:390). A second $\Delta \mathrm{R}$ value from Mangaia gave a $\Delta \mathrm{R}$ result of $-51 \pm 30{ }^{14} \mathrm{C}$ $\mathrm{yr}$, which is in keeping with a value of $-52 \pm 27{ }^{14} \mathrm{C}$ yr for a coral core sequence from Rarotonga, and a second Rarotonga shell $\Delta \mathrm{R}$ value of $11 \pm 17{ }^{14} \mathrm{C}$ yr (Pinctada margaritifera). With the anomalous Mangaia Island value of $219 \pm 20{ }^{14} \mathrm{C}$ yr excluded from the Southern Cook Island average, the 3 remaining values are statistically indistinguishable $\left(\chi_{2: 0.05}^{2}=5.66<5.99\right)($ Table 1$)$.

The impact of hardwaters on ${ }^{14} \mathrm{C}$ only becomes significant in areas where the water exchange with the open ocean is restricted, such as enclosed lagoons or estuaries, resulting in long residence times (i.e. the time a parcel of water remains in a lagoon). The presence of limestone in a particular region is not, therefore, an automatic guarantee of anomalous $\Delta \mathrm{R}$ results (McKinnon 1999:94). In the case of Vava'u Island, blocks of ancient limestone are tilted to the south, resulting in a dissected drowned coastline. This enables the interior waterways to have a connection to the open sea and prevents the freshwater becoming saturated in $\mathrm{CaCO}_{3}$ (Roy 1990). Consequently, the $\Delta \mathrm{R}$ value of $17 \pm 17{ }^{14} \mathrm{C} \mathrm{yr}$ presented in Table 1 is not anomalous when compared to the other South Pacific values (Figure 2). In non-tilted islands, such as Tongatapu, however, a drop in sea level has created an enclosed, noncirculating water body that is supersaturated with dissolved carbonate (Roy 1990).

In many instances, limited information about sample provenance prevents further evaluation of the impacts of hardwater and limestone ingestion by shellfish. We suggest that selection of shell samples from geological or archaeological contexts from such islands is potentially risky and may poorly reflect the age of the samples being dated. Unfortunately, there are few islands in the Pacific where ancient raised coral limestone is not present to some degree (Table 2). The fact that the majority of islands covered in this research are well washed by ocean currents is probably responsible for the limited number of anomalous $\Delta \mathrm{R}$ values observed.

\section{Brackish Water (POC)}

Anomalous marine shell ${ }^{14} \mathrm{C}$ results may also be caused by the ingestion of particulate terrestrial organic matter (either modern or derived from ancient peat or soil) (Keith et al. 1964). This effect, however, tends to be restricted to suspension-feeding shell species that are known to tolerate brackish water conditions (cf. Kaneohe Bay, O'ahu Island, Hawai'i, where the shellfish Macoma dispar- common in areas of freshwater discharge-gave an anomalous $\Delta \mathrm{R}$ value of $-479 \pm 120{ }^{14} \mathrm{C}$ yr [Dye 1994]). Of the shellfish listed in Table 1, Chamidae, Pteriidae, Archidae, Pectinidae, and Ostreidae prefer full-strength, clear seawater and will quickly die if exposed to brackish or freshwater for long periods (Beesley et al. 1998). Some species of Mytillidae and Isognomonidae do, however, occupy brackish environs and can feed on particulate organic matter from a terrestrial source (Beesley et al. 1998:249, 264). Marine shellfish that incorporate a significant proportion of carbon derived from plant or soil sources should exhibit $\delta^{13} \mathrm{C}$ values lower (about -5 to $-10 \%$ ) than that of $100 \%$ marine environments because the decay of $\mathrm{C} 3$ plant material and soil processes depletes $\delta^{13} \mathrm{C}$ (Keith et al. 1964). All shells listed in Table 1 contain stable carbon isotope abundances $\left(\delta^{13} \mathrm{C}\right)$ that fall within or above the typical range of surface ocean DIC (see above), confirming their dependence on marine carbon (Stuiver and Polach 1977:358).

\section{Volcanic Activity}

Volcanic activity has also been suggested as a possible cause of elevated $\Delta \mathrm{R}$ values because of the release of gas depleted in ${ }^{14} \mathrm{C}$ (Petchey et al. 2004, 2008). Shells from 2 active volcanoes in the Pacific have been analyzed: Ambrym Island and Raoul Island. Although Raoul Island is an active volcano with multiple eruptions occurring within the last $1000 \mathrm{yr}$ (Lloyd and Nathan 1981:9), variation between $\Delta \mathrm{R}$ results of different shellfish was found to be minor. Redating of a suspension- 
feeding species (this research) from Ambrym Island enables comparison with a previous result given by Petchey et al. (2004) of a deposit-feeding shellfish $\left(\Delta \mathrm{R}=198 \pm 80{ }^{14} \mathrm{C} \mathrm{yr}\right)$, which may have been influenced by Pliocene and Pleistocene limestone sands from islands $10 \mathrm{~km}$ away. Ambrym is a basaltic island formed by an active shield volcano known for violent phreatic eruptions (McCall et al. 1970). The new $\Delta \mathrm{R}$ value of $67 \pm 30{ }^{14} \mathrm{C}$ yr is higher than the typical South Pacific values presented here (Figure 2), but indistinguishable from the published $\Delta \mathrm{R}$ value of $25 \pm 10{ }^{14} \mathrm{C}$ yr for coral from Espiritu Santo (Burr et al. 1998) $\left(\chi^{2}\right.$ 1:0.05 $=1.76<3.84$; see Table 1). Limited data for the Vanuatu Islands precludes any further assessment, and factors other than volcanic activity may be responsible for the elevated $\Delta \mathrm{R}$ value (e.g. island chain effect, or incorrect date of collection since this could not be independently verified). It is apparent from research into the influence of geothermal activity on ${ }^{14} \mathrm{C}$ (Rubin et al. 1987, Sveinbjörnsdóttir et al. 1992; Pichler et al. 1999) that any effect from volcanic activity tends to be highly localized. Consequently, this remains as a potential cause of anomalies in shell $\Delta \mathrm{R}$ in areas with active volcanic fissures.

\section{Lagoons and Reefs}

Little is known about the effect lagoon or shallow reef environments have on the marine ${ }^{14} \mathrm{C}$ content of shellfish. These environments often incorporate both marine and freshwater aspects that, if sufficiently isolated from the wider oceanic circulation, can result in a unique ${ }^{14} \mathrm{C}$ signature. Ultimately, this will depend on the number and orientation of channels (hoas ${ }^{9}$ and passes) that enable water exchange into the lagoon, prevailing winds and currents, as well as the geomorphology and height of any surrounding reefs. In lagoons where there is limited exchange with the open ocean, water exchange relies primarily on interstitial and atmospheric sources (Andréfouët et al. 2001:401), which can result in $\Delta \mathrm{R}$ extremes such as that documented for the lagoon of Reao Atoll (eastern Tuamotu Archipelago). Reao is a "closed atoll" where exchange with open ocean water occurs via shallow hoa (Salvat 1985). Pirazzoli et al. (1987:66) found that the ${ }^{14} \mathrm{C}$ activity of live corals from within the lagoon was in equilibrium with the atmosphere, while coral from the outer reefs was in equilibrium with seawater (i.e. a difference in apparent age of around $400 \mathrm{yr}$ ) (no ${ }^{14} \mathrm{C}$ values are presented by Pirazzoli et al. [1987]; therefore, they are not included in Table 1). From our data set, only Marutea Sud (Tuamotu Archipelago) is classified as a closed lagoon whereby exchange with the open ocean only occurs during storms (Chevalier 1972) (Table 2). The depleted $\Delta \mathrm{R}$ value of $-47 \pm$ $21{ }^{14} \mathrm{C} \mathrm{yr}$ for Marutea is in keeping with this hypothesis and very different from the $\Delta \mathrm{R}$ of $8 \pm 17{ }^{14} \mathrm{C}$ $\mathrm{yr}$ for shell collected from the reef on Hao Atoll within $30 \mathrm{~km}$ of Marutea $\left(\chi_{1: 0.05}^{2}=4.14<3.84\right)$ (Table 1). Negative values also occur elsewhere in the Pacific in situations where water exchange should be more open (e.g. a $\Delta \mathrm{R}$ value of $-37 \pm 19{ }^{14} \mathrm{C}$ yr for Acrosterigma from Funafuti Atoll, which is classified as an "open" atoll), but since considerable variation in water residence time has been recorded across lagoons (e.g. Atkinson et al. 1981), significant differences in $\Delta \mathrm{R}$ should be expected.

Additional complications to shellfish or coral ${ }^{14} \mathrm{C}$ determinations may be caused by wind and wave action augmenting the transfer of enriched ${ }^{14} \mathrm{CO}_{2}$ from the atmosphere resulting in a more negative $\Delta \mathrm{R}$ value (cf. Forman and Polyak 1997; Hogg et al. 1998). This has been suggested as a cause for the anomalous $\Delta \mathrm{R}$ of $-157 \pm 68{ }^{14} \mathrm{C}$ yr for a sample of Anadara antiquata from the islet of Pangaimotu (Petchey, in press). This islet, offshore from Tongatapu, is surrounded by a shallow reef flat and is exposed regularly at low tide (Richmond and Roy 1986). Enhanced biological production within fertile lagoons environments may also enrich the ${ }^{14} \mathrm{C}$ and $\delta^{13} \mathrm{C}$ of these waters, as has been suggested

\footnotetext{
${ }^{9}$ Shallow passages enabling water exchange with the open ocean are called "hoas." "Passes" are deeper channels that are navigable (Charpy and Dufour 2008).
} 
for depleted $\Delta \mathrm{R}$ values for Norfolk Island (average $\Delta \mathrm{R}=-49 \pm 10{ }^{14} \mathrm{C}$ yr) (Petchey et al. 2008). Consequently, there is no reliable $\Delta \mathrm{R}$ value for Tongatapu.

Negative $\Delta R$ values are common in our data set: e.g. Easter Island ${ }^{10}\left(-113 \pm 18{ }^{14} \mathrm{C}\right.$ yr); Tearia Bank (Gambier Archipelago) $\left(-22 \pm 19{ }^{14} \mathrm{C}\right.$ yr); Poindimié (NC) $\left(-32 \pm 17{ }^{14} \mathrm{C}\right.$ yr); Mangaia $\left(-51 \pm 30{ }^{14} \mathrm{C}\right.$ yr); Rarotonga ( $-52 \pm 27{ }^{14} \mathrm{C}$ yr); Marutea Sud (Tuamotu Archipelago) $\left(-47 \pm 21{ }^{14} \mathrm{C}\right.$ yr); Funafuti Atoll $\left(-37 \pm 19{ }^{14} \mathrm{C}\right.$ yr); and the Fijian samples from Kadavu $\left(-13 \pm 19{ }^{14} \mathrm{C} \mathrm{yr}\right)$, Ono Island $(-16 \pm$ $19{ }^{14} \mathrm{C}$ yr), and Ellington $\left(-18 \pm 19{ }^{14} \mathrm{C}\right.$ yr) (Figure 1 and Table 1). Unfortunately, museum documentation is insufficient in most cases to assign the shellfish to lagoon, atoll, or reef environments; moreover, the conditions encountered in any of these environments can vary widely even over short distances.

\section{CONCLUSION}

This research has provided 31 new $\Delta \mathrm{R}$ values for the South Pacific region. This has enabled an evaluation of $\Delta \mathrm{R}$ by island group and has highlighted a number of potential problems when dating marine shells from Pacific Islands, including the potential impact of large island chains disturbing the surface water flow and the possibility of atolls and lagoons isolating water from the larger ocean reservoir. The most significant impact on $\Delta \mathrm{R}$ value, however, occurs in regions with limestone geology where there is either direct ingestion of limestone by the shellfish or uptake of waters depleted in ${ }^{14} \mathrm{C}$. On the basis of these results, a preliminary regional $\Delta \mathrm{R}$ value has been calculated for each of the island groups that make up New Caledonia $\left(-3 \pm 9{ }^{14} \mathrm{C}\right.$ yr $)$, Southern Cook Islands $\left(-15 \pm 31{ }^{14} \mathrm{C}\right.$ yr), Fiji $\left(11 \pm 26{ }^{14} \mathrm{C}\right.$ yr), the Society Islands $\left(17 \pm 24{ }^{14} \mathrm{C}\right.$ yr $)$, Vanuatu $\left(29 \pm 28{ }^{14} \mathrm{C}\right.$ yr $)$, the Samoan Archipelago $\left(28 \pm 26{ }^{14} \mathrm{C}\right.$ yr $)$, Northern Cook Islands $\left(-2 \pm 14{ }^{14} \mathrm{C}\right.$ yr $)$, Santa Cruz Islands $(26 \pm 11$ ${ }^{14} \mathrm{C}$ yr), and northern Solomon Islands $\left(66 \pm 31{ }^{14} \mathrm{C}\right.$ yr) (Table 1). Of these values, there are limited data for the Vanuatu and Tongan archipelagos. This is of particular concern as these regions are of significant importance to understanding initial human colonization of the Pacific (Burley et al. 1999; Bedford et al. 2006), but are dominated by large areas of exposed limestone (Table 2).

Paleoclimate reconstructions using banded coral core records have indicated that there is long-term temporal marine ${ }^{14} \mathrm{C}$ reservoir variability in some regions of the Pacific, which are tied to periods of climate change (Dunbar and Cole 1996:5; Druffel and Griffin 1993). Fluctuation in sea levels over time in response to climate change is also well documented for the South Pacific islands (Pirazzoli and Montaggioni 1988; Yonekura et al. 1988; Dickinson et al. 1999; Moriwaki et al. 2006). Although climate change will have an influence on the wider marine reservoir, as documented by the coral core records, the impact to the more restricted environs inhabited by many marine shellfish could potentially be of greater significance. Examination of variation in the marine reservoir over time is vital, therefore, if marine shell is to be used to establish chronological control over issues of island colonization and cultural change (Allen 2006; Nunn et al. 2007a,b), or the evaluation of coastal geomorphology and climate change (Yonekura et al. 1988; Moriwaki et al. 2006). The available banded coral core records are, however, few in number, geographically restricted, and may not be subject to the same environmental, and therefore reservoir, conditions as shellfish. Archaeological studies using contemporaneous marine/terrestrial samples (Yoneda et al. 2001; Deo et al. 2004; Ascough et al. 2005) have also demonstrated the importance of longer-term $\Delta \mathrm{R}$ evaluation. Unfortunately, there are only a handful of published $\Delta \mathrm{R}$ values calculated from archaeological marine/ter-

${ }^{10}$ Of 5 coral cores collected from around Easter Island, only 1 exhibited distinct annual growth bands suitable for chronology development (Core Ovahe -97-1). This is attributed to the location of Easter Island at the environmental limits of coral tolerance (Beck et al. 2003; Mucciarone and Dunbar 2003:117, 122) and necessitates caution when using this $\Delta \mathrm{R}$ value. 
restrial pairs from the South Pacific. Moreover, the reliability of these values is currently hindered by problems of association and material suitability (Petchey and Addison 2008). In an attempt to correct this shortcoming, paired marine/terrestrial samples have been selected from archaeological sites of varying age from the Cook Islands, Marquesas, Fiji, and Tongan and Samoan archipelagos. These data are now under analysis.

\section{ACKNOWLEDGMENTS}

We wish to thank Ian Loch (Australian Museum, Sydney), Philippe Bouchet (Museum of Natural History, Paris), Bruce Marshall (National Museum of New Zealand), and Tod Landers and Leslie Newman (Auckland War Memorial Museum, New Zealand) for allowing us access to the shells used in this study. We would also like to thank Paula Reimer (Queen's University, Belfast) for numerous $\Delta \mathrm{R}$ enquiries, George Burr (University of Arizona) for the use of the Marquesan coral data, and David Addison (American Samoan Community College, American Samoa) for casting his critical eye over earlier drafts of this manuscript. This research was funded by a Royal Society of New Zealand Marsden Fast Start grant (UOW0502) awarded to F Petchey.

\section{REFERENCES}

Allen MS. 2006. New ideas about late Holocene climate variability in the central Pacific. Current Anthropology 47(3):521-35.

Almeida FP, Sheehan TF. 1997. Glossary of terms. In: Almeida FP, Sheehan TF, editors. Age Determination Methods for Northwest Atlantic Species. URL: http:// www.nefsc.noaa.gov/fbi/age-man/glos/glostext.htm. Accessed March 2007.

Anderson A, Higham T, Wallace R. 2001. The radiocarbon chronology of the Norfolk Island archaeological sites. Records of the Australian Museum (Supplement) 27:33-42.

Andréfouët S, Pagès J, Tartinville B. 2001. Water renewal time for classification of atoll lagoons in the $\mathrm{Tu}-$ amotu Archipelago (French Polynesia). Coral Reefs 20(4):399-408.

Andrews J, Pickard G. 1990. The physical oceanography of coral reef systems. In: Dubinsky Z, editor. Ecosystems of the World 25: Coral Reefs. Amsterdam: Elsevier. p 11-48.

Ascough P, Cook G, Dugmore A. 2005. Methodological approaches to determining the marine radiocarbon reservoir effect. Progress in Physical Geography 29(4):532-47.

Atkinson MJ, Smith SV, Stroup ED. 1981. Circulation in Enewetak Atoll lagoon. Limnology and Oceanography 26(6):1074-83.

Baker PE, Buckley F, Holland JG. 1974. Petrology and geochemistry of Easter Island. Contributions to Mineralogy and Petrology 44(2):85-100.

Beavan Athfield N, Green RC, Craig J, McFadgen B, Bickler S. 2008. Influence of marine sources on ${ }^{14} \mathrm{C}$ ages: isotopic data from Watom Island, Papua New Guinea inhumations and pig teeth in light of new dietary standards. Journal of the Royal Society of New Zealand 38(1):1-23.
Beck JW, Hewitt I, Burr GS, Loret L, Hochstetter FT. 2003. Mata ki Te Rangi: eyes towards the heavens. Climate and radiocarbon dates. In: Loret J, Tanacredi JT, editors. Easter Island: Scientific Exploration into the World's Environmental Problems in Microcosm. New York: Kluwer Academic. p 93-111.

Bedford S, Spriggs M, Regenvanu R. 2006. The Teouma Lapita site and the early human settlement of the Pacific Islands. Antiquity 80(310):812-28.

Beesley PL, Ross GJB, Wells A, editors. 1998. Mollusca: The Southern Synthesis. Fauna of Australia. Volume 5. Melbourne: CSIRO Publishing. 1234 p.

Beukema JJ. 1989. Molluscan life spans and long-term cycles in benthic communities. Oecologia 80(4):570.

Blake DH, Miezitis Y. 1967. Geology of Bougainville and Buka Islands, New Guinea. Bulletin No. 93. Canberra: Bureau of Mineral Resources, Geology and Geophysics.

British Government, Ministry of Overseas Development. 1976. Geology of Pentecost and Ambrym 1:100,000. New Hebrides Geological Survey, Sheet 6.

British Solomon Islands, Dept. of Geological Surveys 1969. Geological map of the British Solomon Islands. 2nd edition. Scale 1:1,000,000. The British Solomon Islands Geological Record, Volume 111. London: Great Britain Ordnance Survey.

Burley DV, Nelson DE, Shutler Jr R. 1999. A radiocarbon chronology for the Eastern Lapita frontier in Tonga. Archaeology in Oceania 34(2):59-70.

Burr GS, Beck JW, Taylor FW, Récy J, Edwards RL, Cabioch G, Corrège T, Donahue DJ, O’Malley JM. 1998. A high-resolution radiocarbon calibration between 11,700 and 12,400 calendar years BP derived from ${ }^{230} \mathrm{Th}$ ages of corals from Espiritu Santo Island, Vanuatu. Radiocarbon 40(3):1093-105.

Burr GS, Taylor FW, Pandolfi J, Beck JW, Jull AJT, Cor- 
rège T. 2006. Modern and Holocene reservoir ages of South Pacific corals [abstract]. 19th International Radiocarbon Conference, Oxford, England, 3-7 April 2006. Program and Abstracts. $\mathrm{p} 78$.

Campbell IC. 1997. Culture contact and Polynesian identity in the European age. Journal of World History 8(1):29-55.

Charpy L, Dufour P. 2008. Glossary. Exploring Tropical Environments and Societies: The French Polynesian Atolls. The Institute for Research and Development. URL: http://www.com.univ-mrs.fr/IRD/atollpol/glossaire/ukglossa.htm. Accessed November 2008.

Chevalier J-P. 1972. Observations sur les chenaux incomplets appelks hoa dans les atolls des Tuamotu. In: Proceedings of the Symposium on Corals and Coral Reefs 1969. p 477-88. In French.

Chubb LJ. 1927. The geology of the Austral or Tubuai Islands (southern Pacific). Quarterly Journal of the Geological Society of London 83(1-5):291-316.

Chubb LJ. 1930. Geology of the Marquesas Islands. Bulletin 68. Honolulu: Bernice P Bishop Museum. 71 p.

Conchologists List Archives. 2006. Norman Gardner's passing (Sat 19 Aug 2006) [WWW document]. URL: http://listserv.uga.edu/cgi-bin/wa?A2=ind0608c \&L= conch $-1 \& \mathrm{~F}=\& \mathrm{~S}=\& \mathrm{P}=1605$.

Creese R, Hooker S, De Luca S, Wharton Y. 1997. Ecology and environmental impact of Musculista senhousia (Mollusca: Bivalvia: Mytilidae) in Tamaki Estuary, Auckland, New Zealand. New Zealand Journal of Marine and Freshwater Research 31(2):225-36.

Culleton BJ, Kennett DJ, Ingram BL, Erlandson JM, Southon JR. 2006. Intrashell radiocarbon variability in marine mollusks. Radiocarbon 48(3):387-400.

Davidson J. 2002. Richard Kenneth Dell [obituary]. Annual Report of the Royal Society of New Zealand Incorporating the 2002 Academy Council Yearbook. Wellington: Royal Society of New Zealand. http:// www.royalsociety.org.nz/Site/About/Governance/ yearbooks/year02/dell.aspx.

Dell RK. 2005. Oliver, Walter Reginald Brook 1883 1957 [WWW document]. Dictionary of New Zealand Biography. URL: http://www.dnzb.govt.nz/.

Dennis RA. 1981. Section 6. Vanikoro. In: Hugues GW, Craig PM, Dennis RA, editors. Geology of the Eastern Outer Islands. Bulletin 4. Honaira: Solomon Islands Government, Ministry of Natural Resources, Geological Survey Division. p 67-74.

Deo JN, Stone JO, Stein JK. 2004. Building confidence in shell: variations in the marine radiocarbon reservoir correction for the Northwest coast over the past 3,000 years. American Antiquity 69(4):771-86.

Dickinson WR, Burley DV, Shutler Jr R. 1999. Holocene paleoshoreline record in Tonga: geomorphic features and archaeological implications. Journal of Coastal Research 15(3):682-700.

Druffel ERM, Griffin S. 1993. Large variations of surface ocean radiocarbon: evidence of circulation changes in the southwestern Pacific. Journal of Geophysical Research 98(C11):20,249-59.

Druffel ERM, Griffin S, Hwang J, Komada T, Beaupre SR, Druffel-Rodriguez KC, Santos GM, Southon J. 2004. Variability of monthly radiocarbon during the 1760 s in corals from the Galapagos Islands. Radiocarbon 46(2):627-31.

Dunbar RB, Cole JE. 1996. Annual Records of Tropical Systems (ARTS). A PAGES/CLIVAR Initiative. Recommendations for Research. Kauai ARTS Workshop, Sept 1996. Pages Workshop report series 99-1. URL: http://pangea.stanford.edu/research/Oceans/ARTS/ arts_report/arts_report_home.html.

Dye T. 1994. Apparent ages of marine shells: implications for archaeological dating in Hawai' $i$. Radiocarbon 36(1):51-7.

Estabrooks SL. 2007. The possible role of telomeres in the short life span of the bay scallop, Argopecten irradians irradians (Lamarck 1819). Journal of Shellfish Research 26(2):307-13.

Flood AK. 2007. Detection of Bonamia ostreae in fixed Ostrea edulis tissues by use of specific PCR assays [BSc thesis]. Dublin: School of Biological Sciences, Dublin Institute of Technology. $71 \mathrm{p}$.

Forman SL, Polyak L. 1997. Radiocarbon content of prebomb marine mollusks and variations in the ${ }^{14} \mathrm{C}$ reservoir age for coastal areas of the Barents and Kara seas, Russia. Geophysical Research Letters 24(8):885-8.

Frank PW. 1969. Growth rates and longevity of some gastropod mollusks on the coral reef at Heron Island. Oecologia 2(2):232-50.

Ganachaud A, Kessler W, Wijffels S, Ridgway K, Cai W, Holbrook N, Bowen M, Sutton P, Qiu D, Timmermann A, Roemmich D, Sprintall J, Cravatte S, Gourdeau L, Aung T. 2007. Southwest Pacific Ocean Circulation and Climate Experiment (SPICE) - Part I. Scientific Background. International CLIVAR Project Office, CLIVAR Publication Series No. 111. Seattle: NOAA OAR Special Report. NOAA/OAR/PMEL. 37 p.

Gat JR. 1996. Oxygen and hydrogen isotopes in the hydrologic cycle. Annual Review of Earth and Planetary Science 24:225-62.

Goewert A, Surge D, Carpenter SJ, Downing J. 2007. Oxygen and carbon isotope ratios of Lampsilis cardium (Unionidae) from two streams in agricultural watersheds of Iowa, USA. Palaeogeography, Palaeoclimatology, Palaeoecology 252(3-4):637-48.

Gourdeau L, Kessler WS, Davis RE, Sherman J, Maes C, Kestenare E. 2008. Zonal jets entering the Coral Sea. Journal of Physical Oceanography 38(3):715-25.

Gruber N, Keeling CD, Bacastow RB, Guenther PR, Lueker TJ, Wahlen M, Meijer HAJ, Mook WG, Stocker TF. 1999. Spatiotemporal patterns of carbon13 in the global surface oceans and the oceanic Suess effect. Global Biogeochemical Cycles 13(2):307-35.

Guilderson TP, Schrag DP, Goddard E, Kashgarian M, Wellington GM, Linsley BK. 2000. Southwest sub- 
tropical Pacific surface water radiocarbon in a highresolution coral record. Radiocarbon 42(2):249-56.

Guillon JH. 1974. The geology of New Caledonia and the Loyalty Islands. In: Spencer AM, editor. MesozoicCenozoic Orogenic Belts. London: Geological Society of London. p 445-52.

Haws M. 2002. The Basics of Pearl Farming: A Layman's Manual. Center for Tropical and Subtropical Aquaculture publication 127. Hilo: University of Hawaii. $84 \mathrm{p}$.

Heywood KJ, Barton ED, Simpson JH. 1990. The effects of flow disturbance by an oceanic island. Journal of Marine Research 48(1):55-73.

Hogg AG, Higham TFG, Dahm J. 1998. ${ }^{14} \mathrm{C}$ dating of modern marine and estuarine shellfish. Radiocarbon 40(2):975-84.

Hughen KA, Baillie MGL, Bard E, Beck JW, Bertrand CJH, Blackwell PG, Buck CE, Burr GS, Cutler KB, Damon PE, Edwards RL, Fairbanks RG, Friedrich M, Guilderson TP, Kromer B, McCormac G, Manning S, Bronk Ramsey C, Reimer PJ, Reimer RW, Remmele S, Southon JR, Stuiver M, Talamo S, Taylor FW, van der Plicht J, Weyhenmeyer CE. 2004. Marine04 marine radiocarbon age calibration, $0-26 \mathrm{cal} \mathrm{kyr}$ BP. Radiocarbon 46(3): 1059-86.

Hughes GW, Craig PM, Dennis RA. 1981. Geology of the Eastern Outer Islands. Bulletin 4. Honiara: Solomon Islands Government Ministry of Natural Resources.

Jones DS. 1989. Growth rings and longevity in bivalves. American Conchologist 17(1):12-3.

Jones M, Petchey F, Green R, Sheppard P, Phelan M. 2007. The marine $\Delta R$ for Nenumbo: a case study in calculating reservoir offsets from paired sample data. Radiocarbon 49(1):95-102.

Kalish JM. 1993. Pre- and post-bomb radiocarbon in fish otoliths. Earth and Planetary Science Letters 114(4): $549-54$.

Keating BH. 1992. Geology of the Samoa Islands. In: Keating BH, Bolton BR, editors. Geology and Offshore Mineral Resources of the Central Pacific Basin. New York: Springer-Verlag. p 127-78.

Keith ML, Anderson GM, Eichler R. 1964. Carbon and oxygen isotopic composition of mollusk shells from marine and fresh-water environments. Geochimica et Cosmochimica Acta 28(10-11):1757-86.

Kennett DJ, Ingram BL, Erlandson JM, Walker P. 1997. Evidence for temporal fluctuations in marine radiocarbon reservoir ages in the Santa Barbara Channel, Southern California. Journal of Archaeological Science 24(11):1051-9.

Killingley JS, Berger WH. 1979. Stable isotopes in a mollusk shell: detection of upwelling events. Science 205(4402):186-8.

Kirby MX, Soniat TM, Spero HJ. 1998. Stable isotope sclerochronology of Pleistocene and recent oyster shells (Crassostrea virginica). Palaios 13(6):560-9.

Kirch PV. 2004. Environmental and ethnographic back- ground. In: Conte E, Kirch PV, editors. Archaeological Investigations in the Mangareva Islands (Gambier Archipelago), French Polynesia. Contribution \#62, Archaeological Research Facility, University of California, Berkeley. p 16-32.

Konishi K, Tanaka T, Sakanoue M. 1982. Secular variation of radiocarbon concentration in sea water: sclerochronological approach. In: Gomez ED, editor. Proceedings of the Fourth International Coral Reef Symposium. Volume 1. Manila: Marine Science Center, University of the Philippines. p 181-5.

Lillie AR, Brothers RN. 1970. The geology of New Caledonia. New Zealand Journal of Geology and Geophysics 13(1):145-83.

Lloyd EF, Nathan S. 1981. Geology and Tephrochronology of Raoul Island, Kermadec Group, New Zealand. New Zealand Geological Survey Bulletin 95. Wellington: New Zealand Department of Scientific and Industrial Research. 104 p.

Macfarlane A, Carney JN, Harrison W, Tari A, Mallick DIJ. 1983. Geology of North Santo. 1:100,000 New Hebrides Geological Survey Sheet 3. British Government's Directorate of Overseas Surveys for the Government of Vanuatu.

Mallick DIJ, Greenbaum D. 1977. Geology of South Santo. 1:100,000 New Hebrides Geological Survey Sheet 4. British Government's Ministry of Overseas Development (Directorate of Overseas Surveys).

Mangerud J, Bondevik S, Gulliksen S, Hufthammer AK, Høisæter T. 2006. Marine ${ }^{14} \mathrm{C}$ reservoir ages for 19th century whales and molluscs from the North Atlantic. Quaternary Science Reviews 25(23-24):3228-45.

Marshall P. 1927. Geology of Mangaia. Bulletin 36. Honolulu: Bernice P Bishop Museum. 48 p.

Martinez E, Maamaatuaiahutapu K. 2004. Island mass effect in the Marqueasas Islands: time variation. Geophysical Research Letters 31: L18307, doi:10.1029/ 2004GL020682.

McCall GJH, LeMaitre RW, Malahoff A, Robinson GP, Stephenson PJ. 1970. The geology and geophysics of Ambrym Caldera, New Hebrides. Bulletin of Volcanology 34(3):681-96.

McKinnon H. 1999. Investigation of a hard water effect at Aotea Harbour, North Island, New Zealand [unpublished MSc thesis]. Hamilton: University of Waikato.

McMichael DF. 1969. Brazier, John William (18421930). Australian Dictionary of Biography. Volume 3. Melbourne: Melbourne University Press. URL: http:/ /www.adb.online.anu.edu.au/biogs/A030206b.htm.

Messié M, Radenac M-H. 2006. Seasonal variability of the surface chlorophyll in the western tropical Pacific from SeaWiFS data. Deep-Sea Research I 53(10): 1581-600.

Moriwaki H, Chikamori M, Okuno M, Nakamura T. 2006. Holocene changes in sea level and coastal environments on Rarotonga, Cook Islands, South Pacific Ocean. The Holocene 16(6):839-48. 
Mucciarone DA, Dunbar RB. 2003. Stable isotope record of El Niño-Southern Oscillation events from Easter Island. In: Loret J, Tanacredi JT, editors. Easter Island: Scientific Exploration into the World's Environmental Problems in Microcosm. New York: Kluwer Academic. p 113-32.

Murray M, Roach J. 2002. Whitley, Gilbert Percy (19031975). Australian Dictionary of Biography. Volume 16. Melbourne: Melbourne University Press. p 542-3. URL: http://www.adb.online.anu.edu.au/biogs/A160645b.htm.

Nunn PD, Omura A. 1999. Penultimate Interglacial emerged reef around Kadavu Island, Southwest Pacific: implications for late Quaternary island-arc tectonics and sea-level history. New Zealand Journal of Geology and Geophysics 42(2):219-27.

Nunn PD, Hunter-Anderson R, Carson MT, Thomas F, Ulm S, Rowland MJ. 2007a. Times of plenty, times of less: last-millenium societal disruption in the Pacific Basin. Human Ecology 35(4):385-401.

Nunn PD, Ishimura T, Dickinson WR, Katayama K, Thomas F, Kumar R, Matararaba S, Davidson J, Worthy T. 2007b. The Lapita occupation at Naitabale, Mturiki Island, Central Fiji. Asian Perspectives 46(1):96-132.

Oceandots.com. 2008. Funafuti [WWW document]. URL: http://www.oceandots.com/pacific/tuvalu/funafuti.htm.

Paris JP. 1981. Géologie de la Nouvelle-Calédonie: un essai de synthèse. Mémoire du Bureau de Recherches Géologiques et Minières No. 113. In French.

Petchey FJ. 2001. Radiocarbon determinations from the Mulifanua Lapita site, Upolu, western Samoa. Radiocarbon 43(1):63-8.

Petchey FJ. Forthcoming. Dating marine shell in Oceania. In: O'Connor S, Fairbairn A, editors. Proceedings of the 2005 Australasian Archaeometry Conference, Terra Australis. Canberra: ANU E Press.

Petchey FJ, Addison DJ. 2008. Radiocarbon dating marine shell in Samoa: a new $\Delta \mathrm{R}$ from known-age specimens. In: Addison DJ, Asaua TS, Sand C, editors. Recent Archaeology in the Fiji/West-Polynesia Region. University of Otago Studies in Prehistoric Anthropology, 21. Dunedin: Otago University. p 79-86.

Petchey F, Green R. 2005. Use of three isotopes to calibrate human bone radiocarbon determinations from Kainapirina (SAC), Watom Island, Papua New Guinea. Radiocarbon 47(2):181-92.

Petchey F, Phelan M, White JP. 2004. New $\Delta$ R values for the southwest Pacific Ocean. Radiocarbon 46(2): 1005-14.

Petchey F, Anderson A, Hogg A, Zondervan A. 2008. The marine reservoir effect in the Southern Ocean: an evaluation of extant and new $\Delta R$ values and their application to archaeological chronologies. Journal of the Royal Society of New Zealand 38(4):243-62.

Pichler T, Veizer J, Hall GEM. 1999. The chemical composition of shallow-water hydrothermal fluids in $\mathrm{Tu}$ tum Bay, Ambitle Island, Papua New Guinea and their effect on ambient seawater. Marine Chemistry 64(3): 229-52.

Pirazzoli PA, Montaggioni LF. 1988. Holocene sea-level changes in French Polynesia. Palaeogeography, Palaeoclimatology, Palaeoecology 68(2-4):153-75.

Pirazzoli PA, Delibrias G, Montaggioni LF, Saliège JF, Vergnaud-Grazzini C. 1987. Vitesse de croissance latérale des platiers et évolution morphologique récente de l'atoll de Reao, Iles Tuamotu, Polynésie Française. Annales de l'Institut océanographique 63(1):57-68. In French.

Ponder WF, Child M. 1986. Obituary: J. Kerslake. 19151985. Journal of the Malacological Society of Australia 7:179-80.

Pycroft AT. 1935. Santa Cruz red feather money - its manufacture and use. Journal of the Royal Society of New Zealand 44:173-83.

Qiu B, Chen S, Kessler WS. In press. Source of the 70day mesoscale edy variability in the Coral Sea and the north Fiji basin. Journal of Physical Oceanography. doi: 10.1175/2008JPO3988.1.

Reimer PJ, Reimer R. 2005. Marine Reservoir Correction Database. URL: http://intcal.qub.ac.uk/marine/. Accessed November 2005.

Reimer PJ, Reimer RW. 2006. Marine reservoir corrections and the calibration curve. Past Global Changes (PAGES) News 14(3):12-3.

Reimer PJ, McCormac FG, Moore J, McCormick F, Murray EV. 2002. Marine radiocarbon reservoir corrections for the mid- to late Holocene in the eastern subpolar North Atlantic. The Holocene 12(2):129-35.

Richmond BM, Roy PS. 1986. Near shore sediment distribution and sand and gravel deposits in lagoon areas, northern Tongatapu, Tonga. CCOP/SOPAC Technical Report 63. June 1986.

Rick TC, Robbins JA, Ferguson KM. 2006. Stable isotopes from marine shells, ancient environments, and human subsistence on Middle Holocene Santa Rosa Island, California, USA. Journal of Island \& Coastal Archaeology 1(2):233-54.

Ridgway KR, Dunn JR. 2003. Mesoscale structure of the East Australian Current system and its relationship with topography. Progress in Oceanography 56(2): 189-222.

Rodda P, Band RB. 1966. Geology of Viti Levu, Scale 1: 125,000, First Ed. Geological Survey of Fiji, Suva.

Rougerie F, Rancher J. 1994. The Polynesian south ocean: features and circulation. Marine Pollution Bulletin 29(1-3):14-25.

Rougerie F, Wauty B. 1993. L'océanographie du Pacifique Central Sud. In: Atlas de Polynésie Française. ORSTOM editions. p 20-1. In French.

Roy PS. 1990. The morphology and surface geology of the islands of Tongatapu and Vava'u, Kingdom of Tonga. CCOP/SOPAC Technical Report 62. Tonga Project: TG.12.

Rubin M, Lockwood JP, Friedman I. 1987. Effects of volcanic emanations on carbon-isotope content of mod- 
ern plants near Kilauea volcano. In: Decker RW, Wright TL, Stauffer PH, editors. Volcanism in $\mathrm{Ha}$ wai'i. US Geological Survey Professional Paper No. 50. Washington, DC: US Department of the Interior. p 209-11.

Salvat B. 1985. An integrated (geomorphological and economical) classification of French Polynesian atolls. In: Delesalle B, Galzin R, Salvat B, editors. Proceedings of the 5th International Coral Reef Congress. Volume 2. p 337.

Savanier D, Guille G, Maury RC, Blais S, Guillou H, Legendre C, Rossi P. 2003. Geology, petrology and radiochronology of Nuku Hiva (Marquesas Island, French Polynesia). Geophysical Research Abstracts 5: 11,005 .

Schwengel JS. 1957. Theodore Thomas Dranga. The Nautilus 70(4):138-40.

Seurat L-G. 2003. Un naturaliste en Oceanie 1902-1905. Bulletin de la Société des Etudes Océaniennes. Papeete 296/297, February/June. In French.

Signorini SR, McClain CR, Dandonneau Y. 1999. Mixing and phytoplankton bloom in the wake of the Marquesas Islands. Geophysical Research Letters 26(20): 3121-4.

Sikes EL, Samson CR, Guilderson TP, Howard WR. 2000. Old radiocarbon ages in the southwest Pacific Ocean during the last glacial period and deglaciation. Nature 405(6786):555-9.

Smith CH. 2007. Hedley, Charles (England-Australia 1862-1926). Some biogeographers, evolutionists and ecologists: chrono-biographical sketches. URL: http:/ /www.wku.edu/ smithch/chronob/HEDL1862.htm.

Southon J, Kashgarian M, Fontugne M, Metivier B, Yim WW-S. 2002. Marine reservoir corrections for the Indian Ocean and Southeast Asia. Radiocarbon 44(1): $167-80$.

Spennemann DHR, Head MJ. 1998. Tongan pottery chronology, ${ }^{14} \mathrm{C}$ dates and the hardwater effect. Quaternary Geochronology 17:1047-56.

Stern-Pirlot A, Wolff M. 2006. Population dynamics and fisheries potential of Anadara tuberculosa (Bivalvia: Arcidae) along the Pacific coast of Costa Rica. Revista de Biologia Tropical 54 (Supplement 1):87-99.

Stuiver M, Braziunas TF. 1993. Modeling atmospheric ${ }^{14} \mathrm{C}$ influences and ${ }^{14} \mathrm{C}$ ages of marine samples to 10,000 BC. Radiocarbon 35(1):137-89.

Stuiver M, Polach HA. 1977. Discussion: reporting ${ }^{14} \mathrm{C}$ data. Radiocarbon 19(3):355-63.

Stuiver M, Pearson GW, Braziunas T. 1986. Radiocarbon age calibration of marine samples back to $9000 \mathrm{cal} \mathrm{yr}$ BP. Radiocarbon 28(2B):980-1021.

Suess HE 1955. Radiocarbon concentration in modern wood. Science 122(3166):415-7.

Sveinbjörnsdóttir ÁE, Heinemeier J, Rud N, Johnsen SJ. 1992. Radiocarbon anomalies observed for plants growing in Icelandic geothermal waters. Radiocarbon 34(3):696-703.
Tagliabue A, Bopp L. 2008. Towards understanding global variability in ocean carbon-13. Global Biogeochemical Cycles 22: GB1025, doi: 10.1029/ $2007 \mathrm{~GB} 003037$.

Tanaka N, Monaghan MC, Rye DM. 1986. Contribution of metabolic carbon to mollusc and barnacle shell carbonate. Nature 320(6062):520-3.

Taylor RE, Berger R. 1967. Radiocarbon content of marine shells from the Pacific coasts of Central and South America. Science 158(3805):1180-2.

Toggweiler JR, Dixon K, Broecker WS. 1991. The Peru upwelling and the ventilation of the South Pacific thermocline. Journal of Geophysical Research 96(C11): 20,467-97.

Tomczak M, Godfrey JS. 2001. Regional Oceanography: An Introduction. Version 1.0. Oxford: Elsevier Science Ltd. URL: http://www.es.flinders.edu.au/ mattom/regoc/pdfversion.html.

Ulm S. 2002. Marine and estuarine reservoir effects in central Queensland, Australia: determination of $\Delta \mathrm{R}$ values. Geoarchaeology 17(4):319-48.

Ward GK, Wilson SR. 1978. Procedures for comparing and combining radiocarbon age determinations: a critique. Archaeometry 20:19-31.

Waterhouse BC, Petty DR. 1986. Hydrogeology of the Southern Cook Islands, South Pacific. New Zealand Geological Survey Bulletin 98. Wellington: New Zealand Department of Scientific and Industrial Research.

Watters WA. 2006. Marshall, Patrick 1869-1950. Dictionary of New Zealand Biography. URL: http:// www.dnzb.govt.nz/.

Whitley G. 1933. A day in Rarotonga. Mid-Pacific Magazine 45(6):514-5.

Whitley GP. 1975. Ellis le geyt Troughton, CMZS, FRZS (1893-1974). Memorial notice and bibliography. Australian Zoology 18(3):219-37.

Williams H. 1933. Geology of Tahiti, Moorea and Maiao. Bulletin 105. Honolulu: Bernice P Bishop Museum. $89 \mathrm{p}$.

Wood BL. 1967. Geology of the Cook Islands. New Zealand Journal of Geology and Geophysics 10: 1429-45.

Wood BL, Hay RF. 1970. Geology of the Cook Islands. New Zealand Geological Survey Bulletin 82. Wellington: New Zealand Department of Scientific and Industrial Research. 103 p.

Yoneda M, Hirota M, Uchida M, Uzawa K, Tanaka A, Shibata Y, Morita M. 2001. Marine radiocarbon reservoir effect in the western North Pacific observed in archaeological fauna. Radiocarbon 43(2A):465-71.

Yonekura N, Ishii T, Saito Y, Maeda Y, Matsushima Y, Matsumoto E, Kayanne H. 1988. Holocene fringing reefs and sea-level change in Mangaia Island, Southern Cook Islands. Palaeogeography, Palaeoclimatology, Palaeoecology 68(2-4):177-88. 


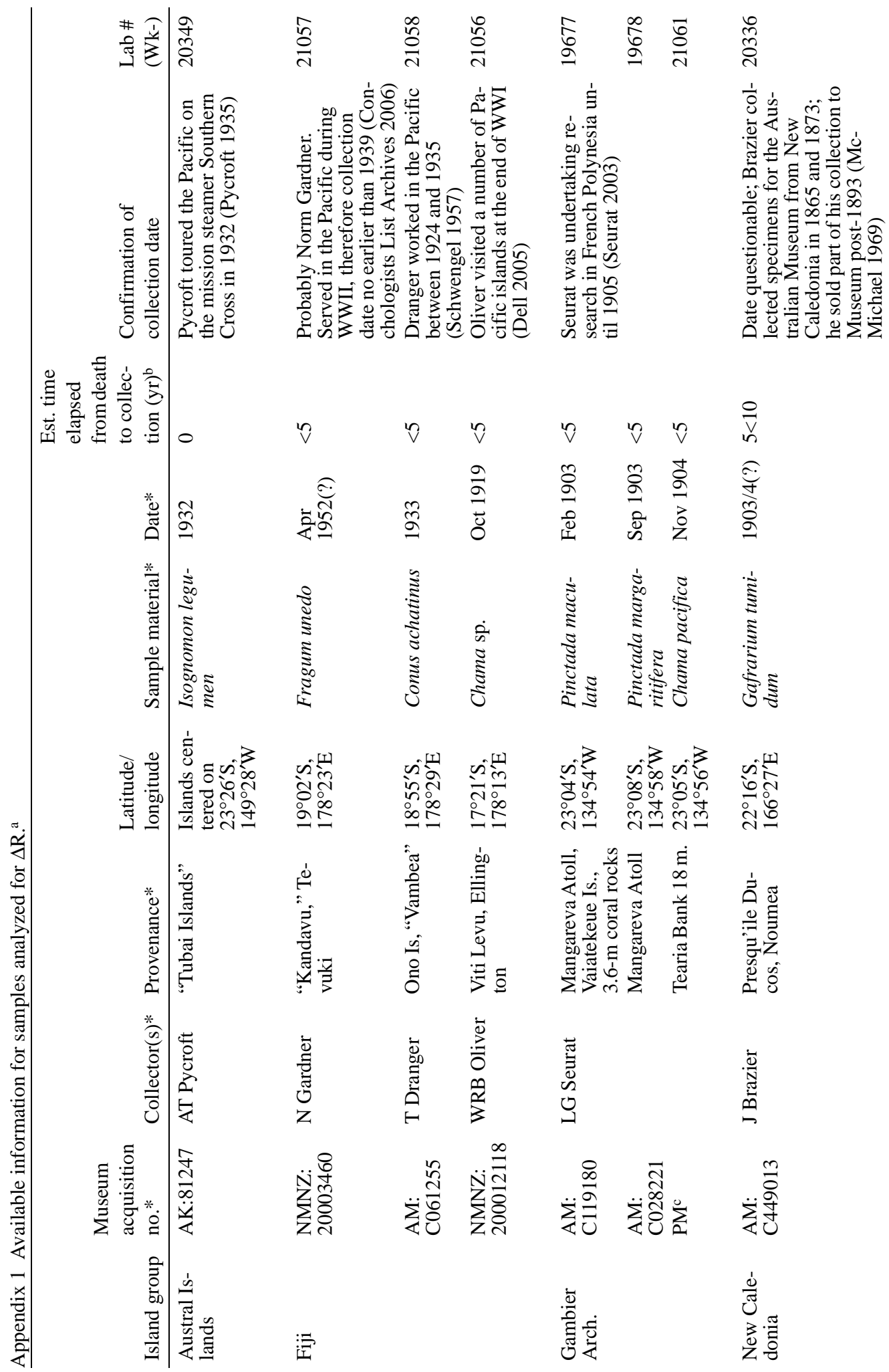




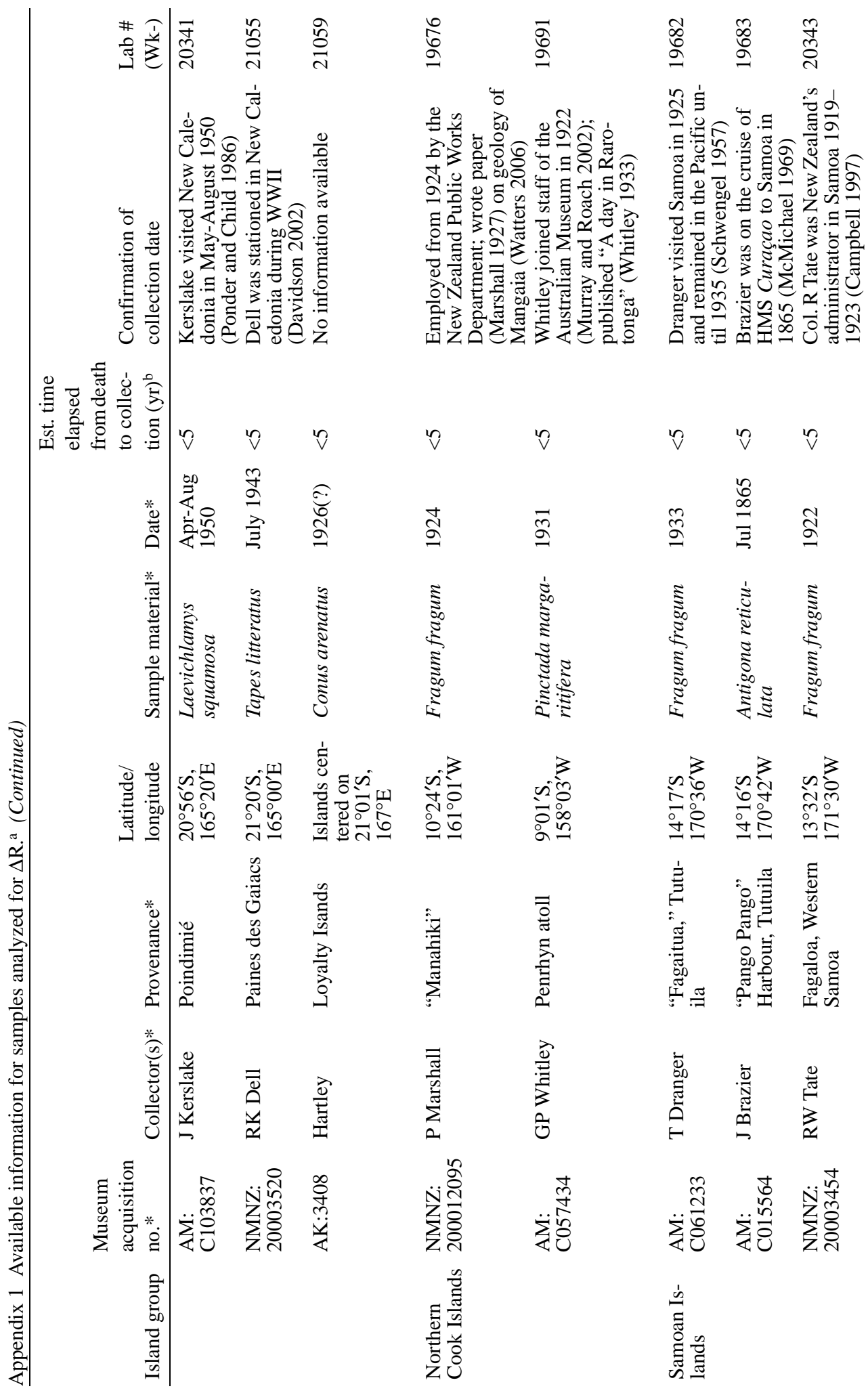




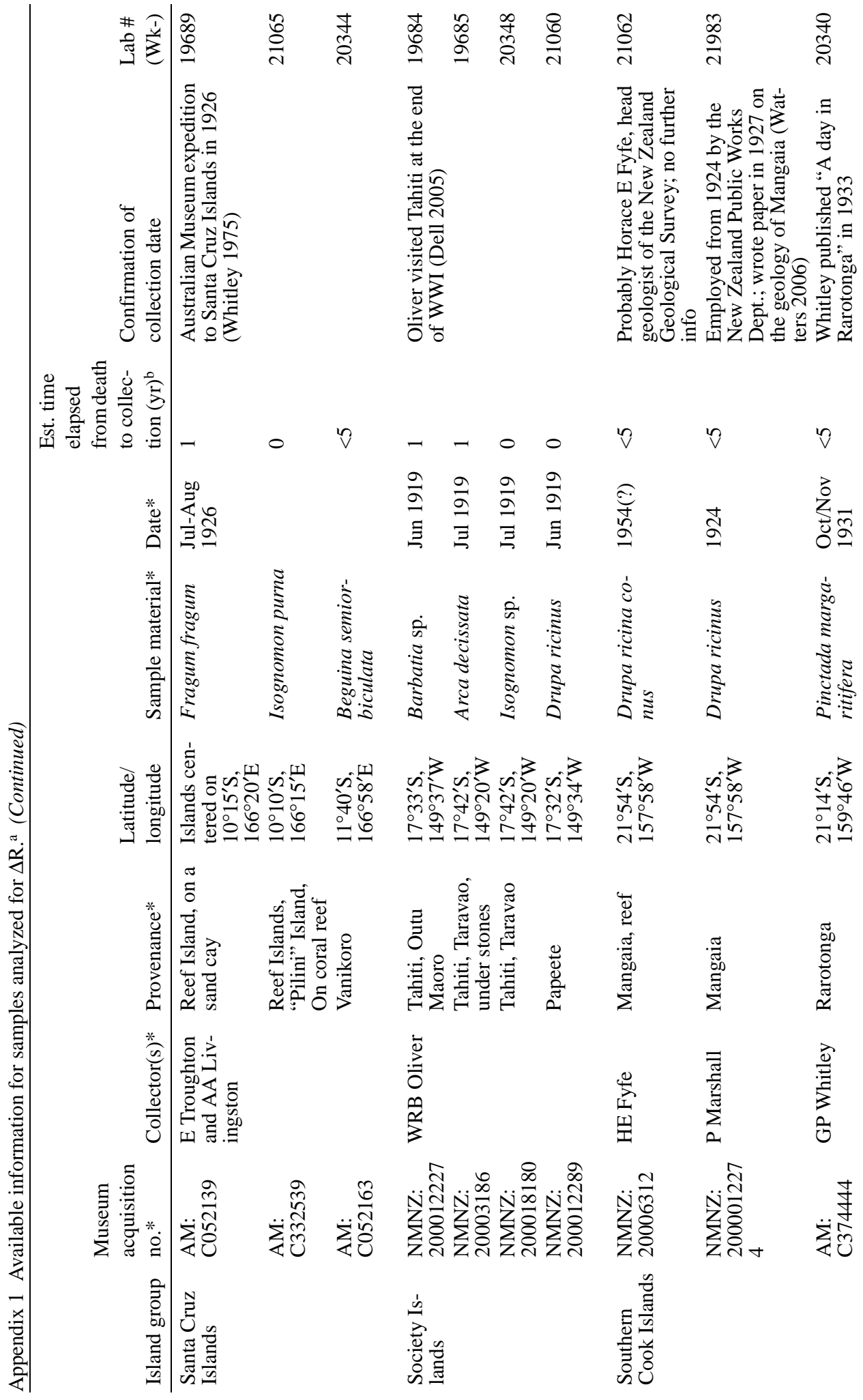




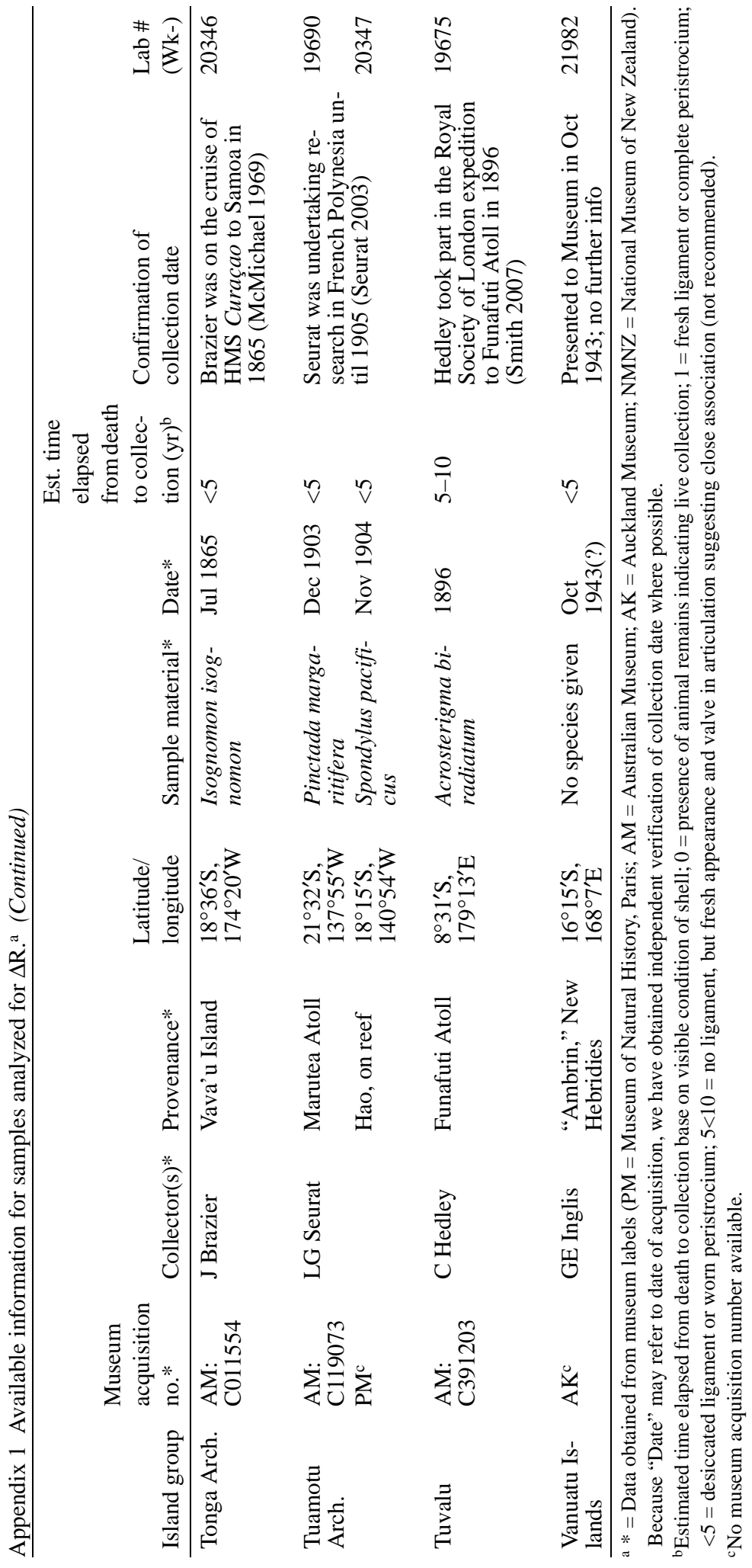

